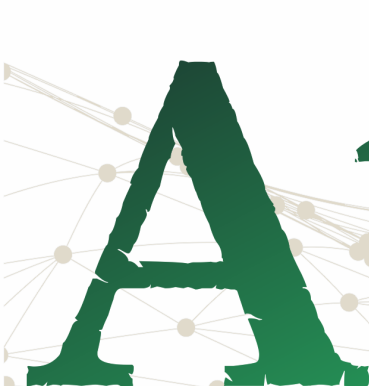

ISSN n² 2526-8031

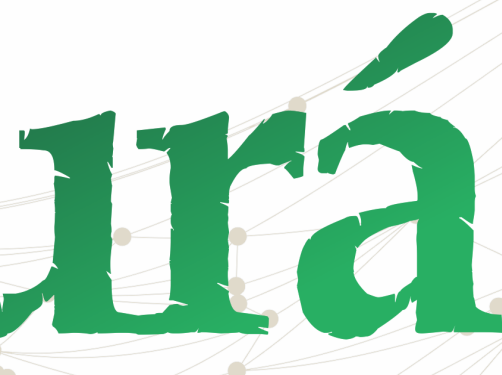

Vol. 4, n. 2, Maio-Agosto. 2020
Revista

Pan-Amazônica

de Comunicação

DOI: http://dx.doi.org/10.20873/uft.2526-8031.2020v4n2p121

\title{
ENCANTARIA MODERNA: COMUNICAÇÃO, XAMANISMO E FEITIÇARIA
}

Comunicación, chamanismo y hechicería

Communication, shamanism and sorcery

Marcelo Bolshaw Gomes, Universidade Federal do Rio Grande do Norte ${ }^{1}$

\section{RESUMO}

Muito tem sido escrito sobre a necessidade de assimilar os saberes ancestrais ao conhecimento científico. Esse texto tem o objetivo pensar a comunicação na cosmovisão ameríndia. Para tanto, distingue-se o neoxamanismo urbano dos xamanismos arcaicos. Elencadas as diferenças positivas e negativas, há dois pontos em comum (a transcendência em relação aos sistemas de crenças e a cura transferencial como prática) e quatro princípios mágicos utilizados para hipnose e venda de produtos-conceitos.

PALAVRAS-CHAVE: Comunicação midiática; Antropologia; Estudos Amazônicos.

\section{ABSTRACT}

Much has been written about a need similar to ancient knowledge to scientific knowledge. This text aims to think about communication in the American worldview. For this, urban neo-shamanism is distinguished from archaic shamanisms. Listed as positive and negative differences, there are two points in common (a transcendence in relation to crime systems and a transferential cure as a practice) and four magical principles used for hypnosis and sale of concept products.

KEYWORDS: Media communication; Anthropology; Amazonian Studies.

\section{RESUMEN}

${ }^{1}$ Mestre e doutor em Ciências Sociais. Professor do Programa de Pós-Graduação em Estudos da Mídia (UFRN). E-mail: marcelobolshaw@gmail.com 


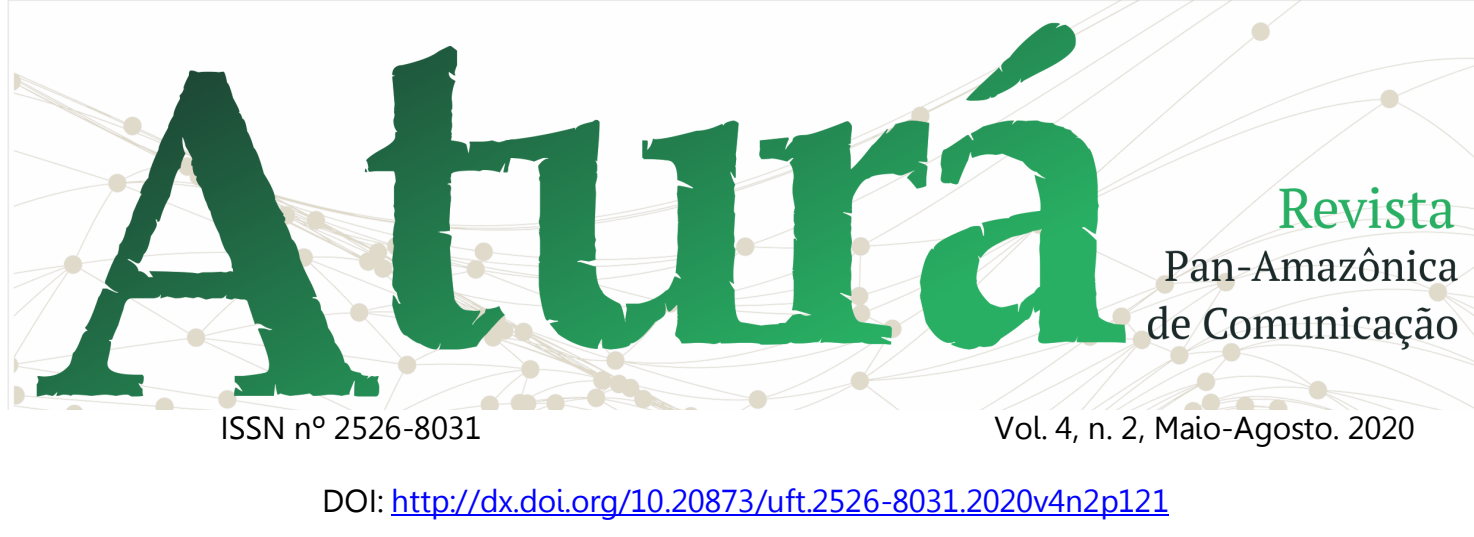

Se ha escrito mucho sobre una necesidad similar al conocimiento antiguo al conocimiento científico. Este texto tiene como objetivo pensar en la comunicación en la cosmovisión americana. Para ello, el neo-chamanismo urbano se distingue de los chamanismos arcaicos. Listados como diferencias positivas y negativas, hay dos puntos en común (una trascendencia en relación con los sistemas de delincuencia y una cura transferencia como práctica) y cuatro principios mágicos utilizados para la hipnosis y la venta de productos conceptuales.

PALABRAS CLAVE: Comunicación con los medios de comunicación; Antropología; Estudios amazónicos.

Recebido em: 12.02.2020. Aceito em: 14.04.2020. Publicado em: 01.05.2020. 


\section{A \\ ISSN n² 2526-8031 \\ Vol. 4, n. 2, Maio-Agosto. 2020 \\ Pan-Amazônica \\ de Comunicação \\ DOI: http://dx.doi.org/10.20873/uft.2526-8031.2020v4n2p121}

\section{Introdução}

A história da antropologia pode ser subdividida em três grandes momentos: o período evolucionista e etnocêntrico, em que os antropólogos consideravam os outros povos primitivos; o período funcionalistaestruturalista, em que Franz Boas e LéviStrauss, entre outros, se descobriram iguais aos selvagens que estudavam; e o período etnoantropológico, em que, invertendo a perspectiva inicial, o antropólogo se conhece cultural e psicologicamente através de tradição que estuda e torna-se um xamã.

No decorrer de suas pesquisas, o antropólogo encontra o xamanismo e se apaixona. Passado algum tempo, percebe que conhece apenas uma adaptação ideológica das práticas do passado. Para curar-me parcialmente dessa ilusão e como prova de agradecimento sincero pela compreensão que me foi generosamente entregue, escrevo aqui uma comparação entre o passado e o presente

\section{A abordagem platônica do mito}

Acorrentados de costas para a luz em um cárcere subterrâneo, os prisioneiros só podem ver, dos homens, animais e figuras que passam pelo exterior, as sombras projetadas no fundo da Caverna. Quando um dos prisioneiros se liberta e retorna ao mundo exterior, é cego pela luminosidade do Sol e só aos poucos consegue se adaptar à nova realidade. Percebe, então, que o mundo no qual vivia era irreal e inconsciente, feita de sombras e reflexos das coisas.

O prisioneiro correria sério risco de vida se, retornando ao interior da caverna, procurasse revelar aos seus antigos companheiros a irrealidade do mundo em que se encontram. Provavelmente, eles o matariam.

$\mathrm{Na}$ imagem genial da caverna, Platão não apenas resumiu sua concepção sobre realidade sensível e realidade inteligível, mas também nos transmitiu sua experiência pessoal, mais precisamente, sua explicação filosófica para o trágico destino de seu mestre, Sócrates, forçado a beber veneno pelas 


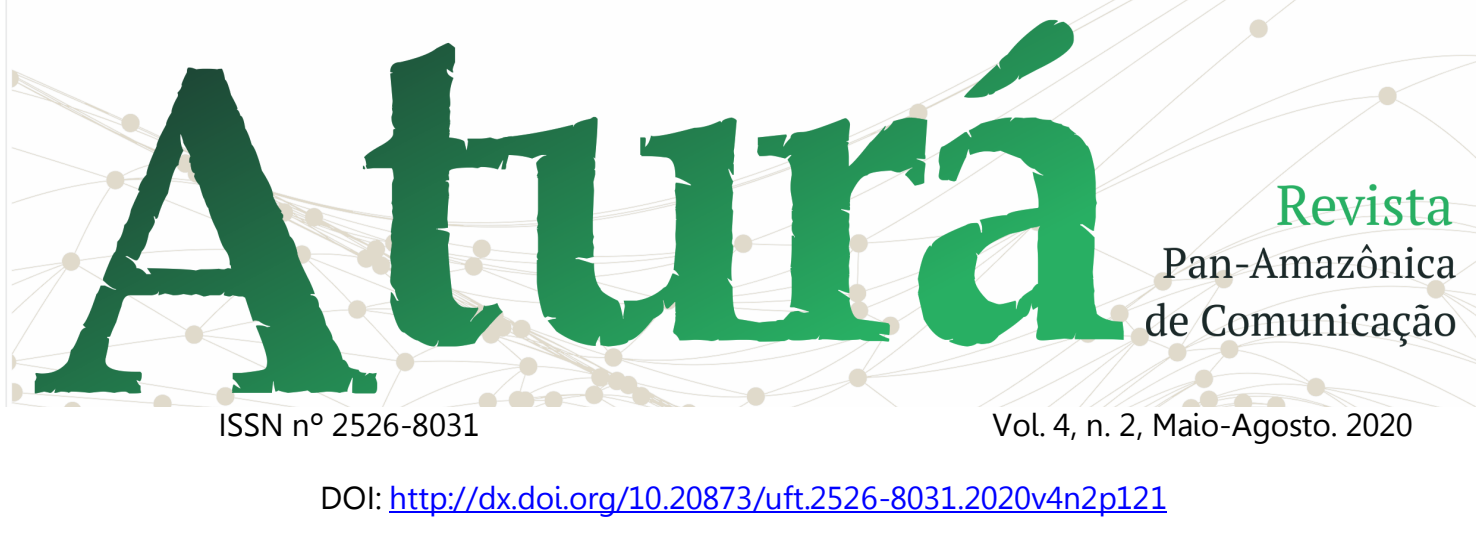

autoridades atenienses em virtude de sua defesa intransigente de uma visão mais objetiva da realidade.

Na Idade Média, Santo Agostinho, no livro A Cidade de Deus (AGOSTINHO, 1990), retoma a ideia de utopia platônica em uma perspectiva histórica. Para o criador da doutrina do pecado original, a Cidade de Deus existe paralela à Cidade dos Homens: as realidades sensível e inteligivel de Platão. Ao ser expulso do paraíso, o homem dissociou os dois mundos e o retorno à Nova Jerusalém será a reunificação das cidades. Agostinho colocou a utopia platônica como um objetivo histórico da humanidade, ideia que se será adotado involuntariamente por muitos pensadores posteriores.

Outra adaptação/atualização do pensamento platônico pode ser atribuída a C. G. Jung e aos conceitos de Arquétipos e Inconsciente Coletivo (JUNG, 2002).

Nessa versão, o mundo inteligível, o lado de fora da caverna, é uma memória coletiva de imagens arcaicas acessível através dos sonhos e da mitologia. Essa mente coletiva arcaica é formada por Arquétipos, representações coletivas e universais, presentes em diferentes culturas. Palas Atenas, o Júpiter latino e o orixá Xangô, por exemplo, são diferentes representações históricas do arquétipo da justiça, que tem suas raízes em um dispositivo psicológico que equilibra transgressão e culpa.

Joseph Campbell (1990;1995), levou as ideias de Jung aos campos da arqueologia e mitologia comparada, elaborando um modelo universal Segundo o qual todos os grandes mitos fundadores das culturas humanas seriam, em última análise, uma única narrativa: o 'monomito' ou a jornada do herói.

E historiador das religiões Mircea Eliade elaborou uma arqueologia estrutural dos mitos (uma ampla classificação dos mitos por arquétipos), principalmente no livro Tratado Histórico das Religiões (1993). Nessa arqueologia, 


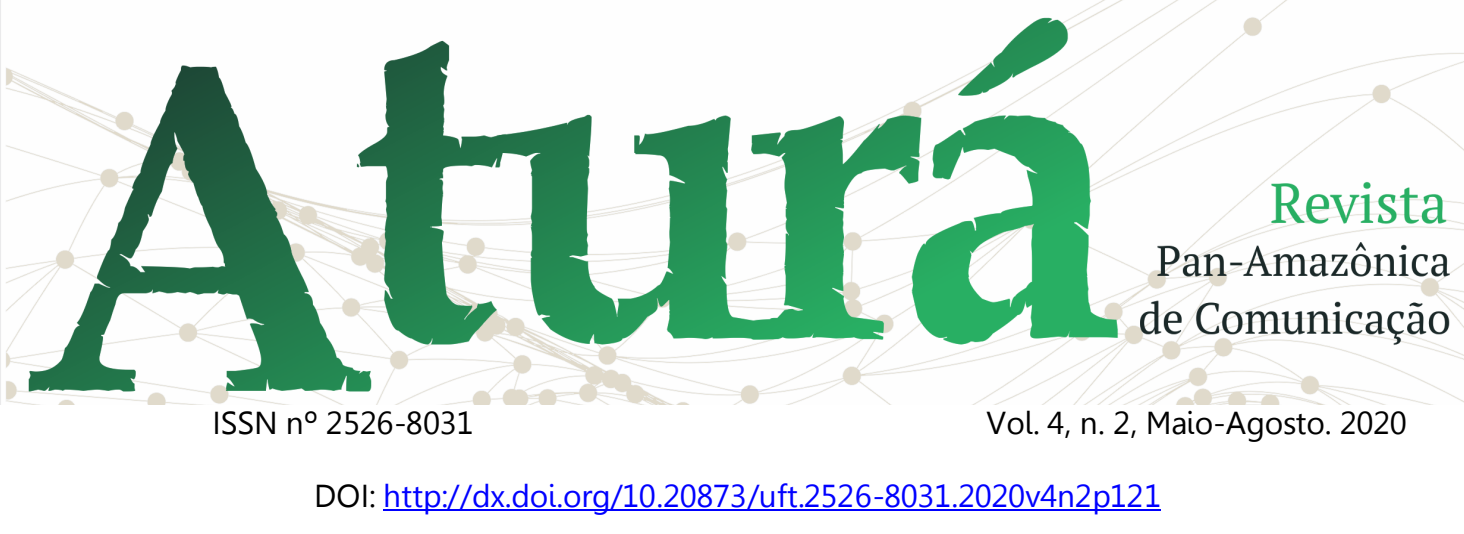

há duas formulações particularmente importantes: o 'centro do mundo' e o 'monoteísmo primitivo'.

Para Eliade (1992, p.295-312), a noção de 'Centro do Mundo' faz parte do universo de praticamente todas as sociedades arcaicas. $O$ universo foi criado a partir desse centro e é uma passagem tanto para os infernos subterrâneos como para regiões celestiais. Tal é o sistema simbólico das sociedades tradicionais, do qual derivam as imagens cosmológicas, os mitos e concepções religiosas nas mais diversas culturas: os pilares, as montanhas sagradas, as árvores da vida, as escadas cósmicas são representações do Axis Mundi, em torno do qual o universo se organiza. Para os judeus, o monte Tabor é o Centro do Mundo; enquanto, para os gregos, é o Olimpo. O monte Meru dos hindus, o Himinghjor dos germânicos, o Haraberezaiti dos iranianos, a Kaaba dos islamitas, Jerusalém para os cristãos todos são passagens verticais para outras dimensões e se situam no Centro do Mundo dessas cosmovisões. Eliade acredita ainda que nas sociedades mais antigas a "imagem visível deste pilar cósmico é, no céu, a Via Láctea", que se expande a partir da constelação da Ursa Maior (polo norte estelar, possível local do 'Big Bang') e se direciona para um buraco negro abaixo da constelação do Cruzeiro do Sul (polo sul estelar).

Outra formulação significativa é que, possivelmente, o politeísmo é uma invenção judaico-cristã. Eliade (1993, p.39-102) após estudar diversas mitologias tidas como 'politeístas', observou que deuses celestes como Tangri, Urano e Olorum não tinham altar ou culto e eram 'pais' dos outros deuses, a quem entregou a administração do mundo. Elaborou as categorias de 'deus oticius' e de 'monoteísmo primitivo'. E essa forma universalista de pensar arquetipicamente o mito é hegemônica não somente em vários campos de estudo, mas também em vários grupos esotéricos atuais - que se fundamentam em autores como Jung e Campbell buscando dar uma maior credibilidade a suas crenças e práticas rituais. 


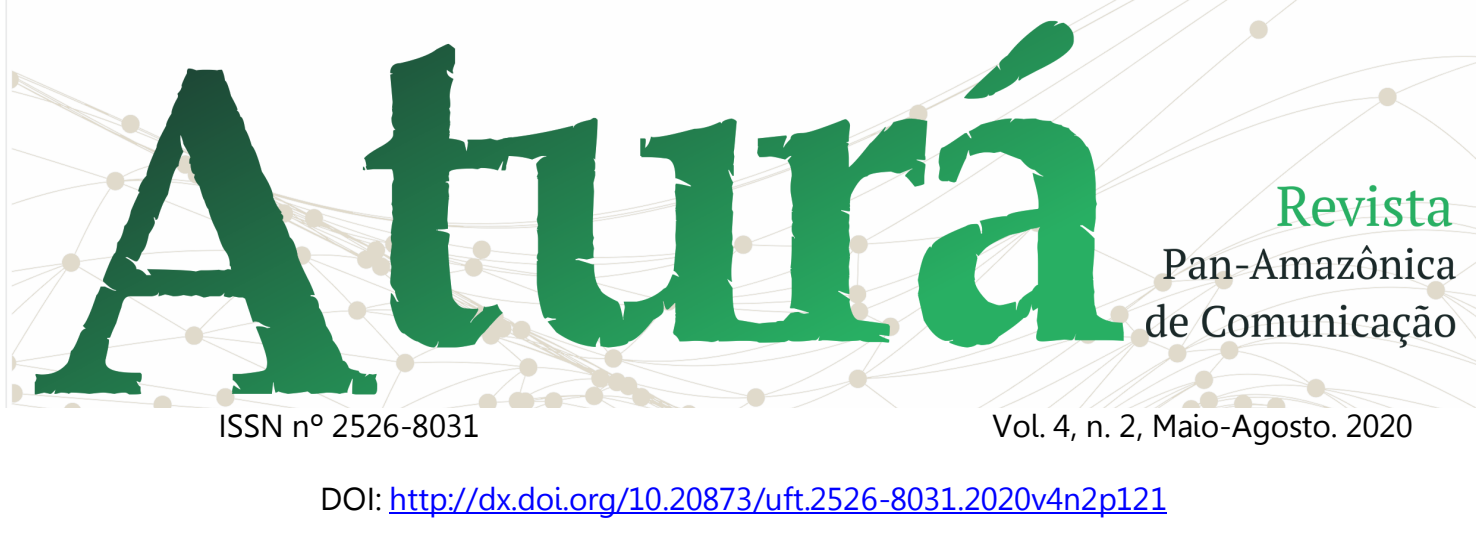

\section{A visão antropológica do mito}

Porém, o maior e mais completo estudo sobre a universalidade do mito é a tetralogia 'Mitológicas' de Lévi-Strauss (2004; 2005; 2006; 2011). Após, estudar, durante 20 anos, diferentes mitologias ameríndias, o antropólogo passou a crer, senão na unidade primordial de todos os mitos, pelo menos da universalidade da experiência mítica. Lévi-Strauss não só explicou cientificamente o significado cultural do mito (em suas particularidades linguísticas, econômicas e hereditárias), mas pôs-se a pensar (parcialmente) como selvagem.

Jung, Campbell e Eliade partem do geral (do inconsciente coletivo, dos arquétipos) para o particular (os mitos culturais específicos) e são universalistas, cultuando o sagrado como uma epifania transcultural. Enquanto a antropologia, no sentido contrário, descreve o aspecto local das narrativas míticas dentro de um quadro aberto de referências linguísticas, alimentares, culturais. Ambos abordam 'o todo e as partes' - mas de modo bem diferente, inverso e até complementar em alguns aspectos. Os antropólogos são mais indutivos; os mitólogos, mais dedutivos.

Lévi-Strauss chega à mesma conclusão que os mitólogos, mas por caminhos muitos mais tortuosos, fragmentados e complexos: a análise estrutural de 813 mitos com algumas variantes, de culturas nativas das duas Américas.

Ressalte-se também que ideia de um único mito arcaico de dimensões continentais é bastante diferente da noção de monomito universal de Campbell e da jornada do herói. Na ótica da antropologia, os mitólogos se deixam possuir pelo mito sem perceber e, muitas vezes, acabam tecendo generalizações etnocêntricas, adequando outras mitologias à sua. Para estudar um mito, é necessário se distanciar culturalmente dele e vê-lo de fora. E a importância da experiência mítica de um homem desencantado, como Lévi-Strauss, é 


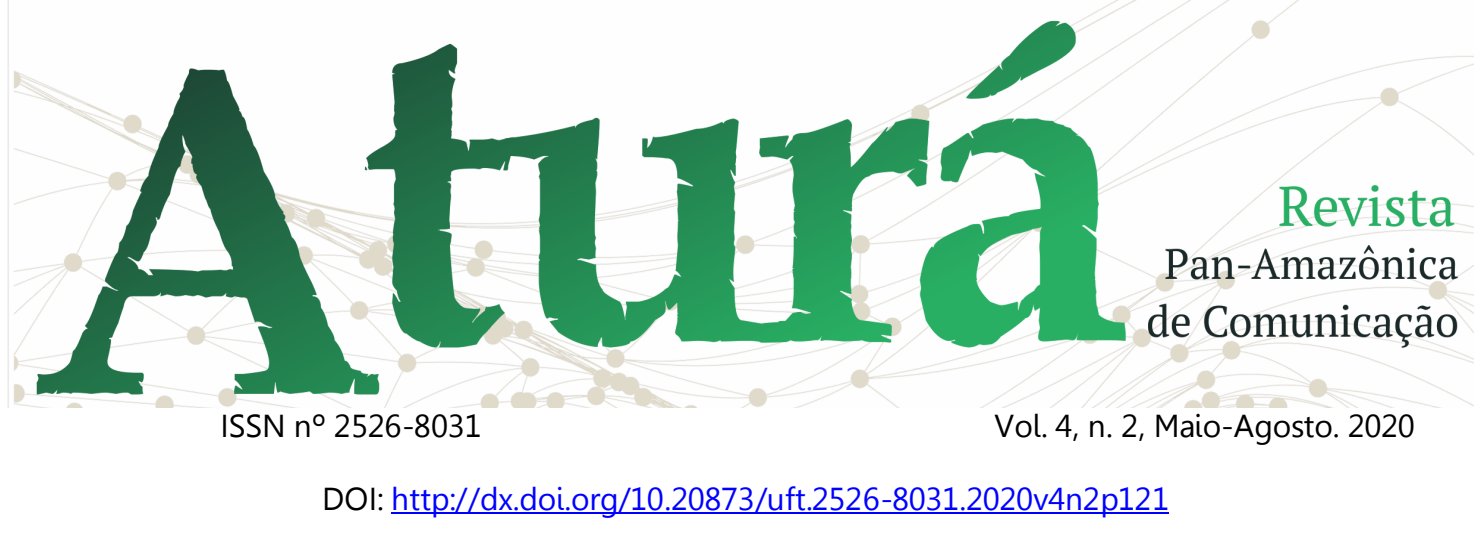

justamente que ele vê (e vive) o mito ao mesmo tempo como cientista e como selvagem, sem abrir mão de nenhum dos dois lados. A conclusão de Strauss de que todos os mitos são um só, não é só devida às semelhanças de personagens $e$ ações dramáticas nas diferentes narrativas, mas, sobretudo, ao fato das estruturas narrativas se perpetuarem tendo a si mesmo como referência, sempre contando sua própria história.

O pensamento selvagem classifica as coisas (cores, sons, cheiros, animais, datas, pessoas) segundo critérios subjetivos derivados de experiências sensoriais; em oposição ao pensamento científico domesticado, que classifica o mundo segundo critérios objetivos universais. Mas, o 'pensamento selvagem' de Strauss não é o 'pensamento dos selvagens', mas sim o pensamento em estado selvagem, ainda não domesticado. Ele não é incompatível com o pensamento científico. O pensar selvagem se refere a propriedades sensíveis; o pensar científico se refere às propriedades abstratas. Assim, o pensamento antropológico é selvagem e civilizado ao mesmo tempo, não separando os dois lados da caverna, observando uma única realidade de modo sensível e inteligível simultaneamente.

Enquanto a psicologia analítica de Jung e suas derivações (Bachelard, Campbell, Eliade) estudam o mito do ponto de vista platônico e universal; a antropologia valoriza mais a estrutura dos mitos do que seu conteúdo manifesto, como se eles fossem mensagens fragmentadas do passado, que, com o passar do tempo, quase perderam o sentido. Defende-se aqui que os dois métodos não se excluem e são complementares na investigação das ressonâncias subjetivas das narrativas míticas.

\section{A reinvenção do xamanismo}

O xamanismo está se tornando uma nova forma de espiritualidade global, atraindo jovens de várias partes do planeta, misturando diferentes 


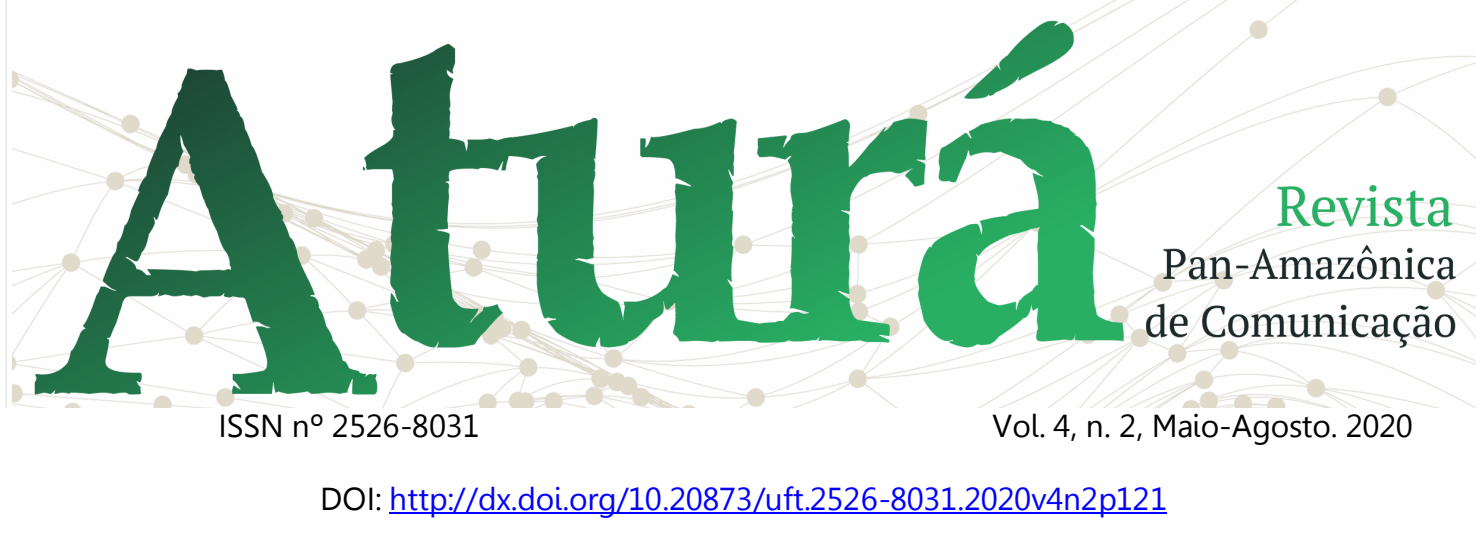

tradições indígenas na espiritualidade pós moderna, new age. A palavra "Shaman" é de origem siberiana (Tungue) e significa 'feiticeiro'. O historiador Mircea Eliade, em seu livro $O$ Xamanismo e as Técnicas Arcaicas do Êxtase (2002) considera que o complexo xamânico, além existir em todos os povos da Ásia Central e Setentrional (árticos, turco-mongóis, himalaios), está presente ainda no Extremo Oriente (Japão, Coreia, Indochina), da Oceania (Austrália, Havaí), em diferentes regiões da África (Bantos, Yorubás, Ewes) e nas duas Américas.

Por 'complexo xamânico', o historiador entende a presença de vários elementos em comum: o tambor, os maracás, o tabaco, a fogueira sagrada, o contato com os deuses e ancestrais, a doença iniciática (morte e ressureição do xamã), a cura de doenças através da sucção, a 'visão do esqueleto', entre outras. O xamanismo não é um sistema de crenças religiosas propriamente dito, mas um conjunto de práticas extáticas e terapêuticas cujo objetivo é entrar em contato com o a realidade invisível. Coexiste com várias tradições (escritas e orais) e está presente nos cinco continentes. Eliade considera que não são as formas religiosas que o caracterizam, mas sim as práticas extáticas e uma maior intensidade espiritual que a experiência religiosa da maioria das pessoas de cada tradição.

O xamã, deste ponto de vista geral, não é apenas o feiticeiro, o medicine-man ou o vidente de uma comunidade tribal, que conhece a energia da natureza e a utiliza em rituais em benefício do grupo; ele é sobretudo o 'psicopompo' (o guia condutor das almas mortas, o viajante dos céus e dos infernos através de transes místicos) e pode desempenhar, segundo a região e a tradição a que pertença, as funções de sacerdote, místico e poeta. O xamã é sempre o grande sonhador, o mediador com o mundo invisível, o personagem que vive no encontro entre duas realidades. 


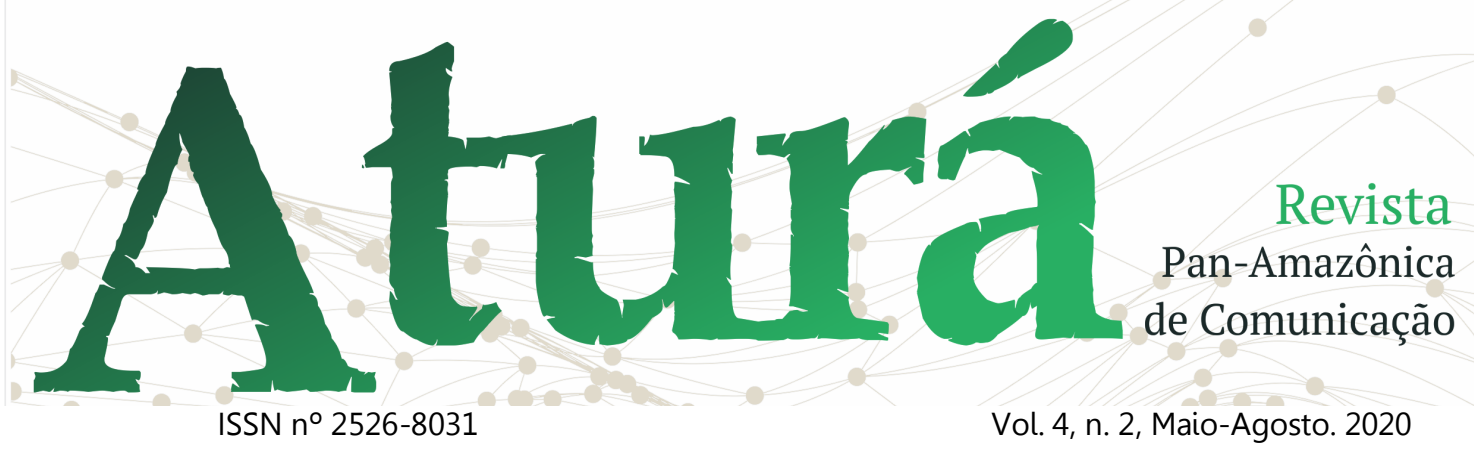

DOI: http://dx.doi.org/10.20873/uft.2526-8031.2020v4n2p121

Porém, nos dias atuais: "Ser xamã, é viver uma vida comum de forma extraordinária. É saber ler os sinais claros, que 'falam' conosco, nas entrelinhas dos acontecimentos" - como explica Carminha Levy, no site Vya Estelar²:

\begin{abstract}
A tradução da palavra xamã é "aquela que sabe". É aquele que faz a descoberta da consciência. O sacrifício do xamã é a busca da autoconsciência, sacrificando o ego, ou seja, todos os aspectos negativos do ser, nos níveis espiritual, mental, emocional e físico. O trabalho do xamã consiste em sair fora do corpo, em estado alterado de consciência, utilizando a imaginação, ou saindo fora do corpo mesmo. Isto acontece quando a pessoa trabalha com fenômenos fora do corpo. Enfim, todos os seres são xamãs. Mas precisam ser acordados para este dom. Geralmente, as pessoas despertam para o xamanismo através de uma doença, um acidente ou a perda de um ente querido...
\end{abstract}

Segundo essa ótica, músicos, poetas, escritores, pintores, escultores, atores, bailarinos, cineastas, todos que

\footnotetext{
${ }^{2}$ Xamanismo: Caminho de autocura para uma vida extraordinária. Nesta entrevista a professora de xamanismo Carminha Levy, elabora um teste para você saber se é um xamã, explica por que a apresentadora Angélica é uma xamã. Carminha é iniciada no xamanismo há 26 anos, é discípula do antropólogo americano Michael Harner. < http://www2.uol.com.br/vyaestelar/vya estela15. $\underline{\mathrm{htm}}>$
}

tenham uma ligação especial com natureza e que vivam com o lado direito do cérebro, onde exercita seu lado intuitivo, instintivo e criativo - são meio xamãs. Também os médicos, enfermeiros, psicólogos, terapeutas e psiquiatras são xamãs por excelência. Todo curador, criativo ou religioso é um xamã, mesmo que totalmente dissociado de rituais arcaicos de êxtase e das culturas ancestrais.

A passagem dos 'xamanismos locais tradicionais' para o neoxamanismo global se deve, principalmente, a dois antropólogos, que, na década de 60, trocaram a perspectiva científica pela visão dos saberes ancestrais: Carlos Castañeda e Michael Harner.

Castaneda reinventa o xamanismo tolteca de forma pós-moderna, adaptando-o para a vida cotidiana atual através de uma 'ética do guerreiro'; e Michael Harner resgata o essencial do antigo xamanismo para espiritualidade contemporânea: a ênfase na autocura ou na canalização/transformação do 


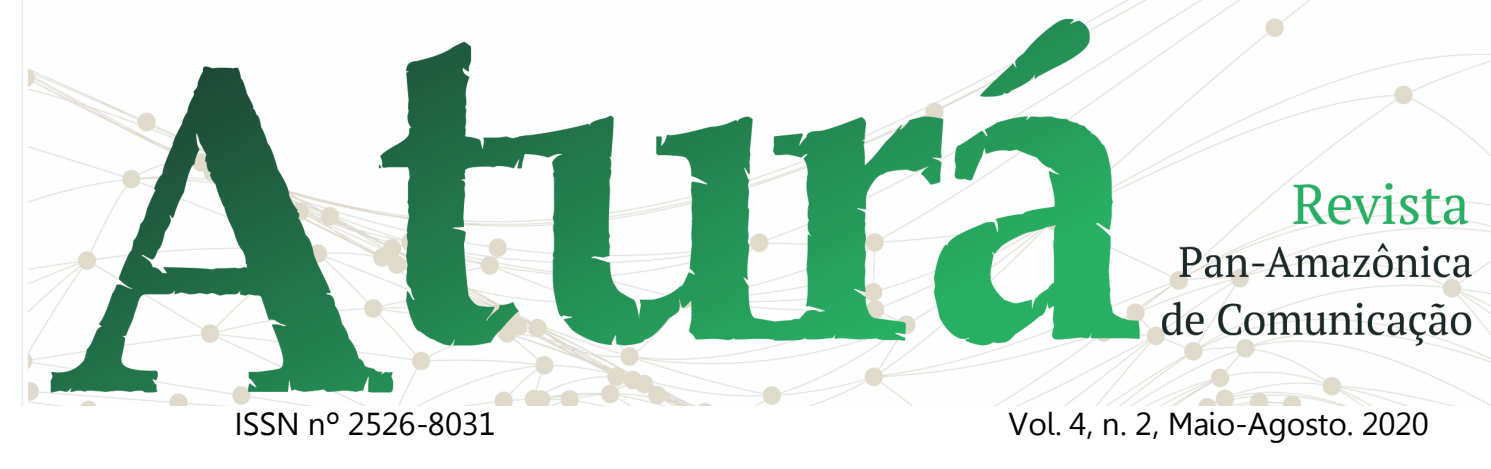

DOI: http://dx.doi.org/10.20873/uft.2526-8031.2020v4n2p121

negativo em positivo. Pode-se até distinguir dois grupos diferentes de neoxamanismo a partir dessas duas influências de transição, uma mais voltada para o descondicionamento social; e outra mais platônica e gnóstica.

E a partir do sucesso desses dois escritores, surgiu um novo xamanismo universal que combina diferentes ideias e técnicas, desenraizadas culturalmente de suas origens geográficas, voltadas para a (auto) regeneração planetária e para a (re) integração com meio ambiente. Há também xamanismo étnicos que se globalizam, gerando um turismo de desenvolvimento pessoal: como a Sun Dance dos Sioux; o peiote dos Navarro nos EUA; e o San Pedro, a ayahuasca e a coca, no Peru. No Brasil, há controvérsias extensas sobre o caráter xamânico das religiões ayahuasqueiras ${ }^{3}$.

3 A aproximação entre o Santo Daime e o xamanismo, por exemplo, é polemizada por vários autores (LABATE, 2002, p. 240-242). Segundo Clodomir Monteiro (1983), o Santo Daime está inserido em um contexto de práticas xamânicas, marcado por transes xamânicos individuais e coletivos; seus líderes são equivalentes a xamãs. Couto (1989) desenvolve
Embora xamãs e antropólogos aceitem a distinção entre os antigos xamanismos locais e o crescente neoxamanismo urbano (MAGNANI, 1999a; 1999b; 2000; 2005), na prática existe uma grande confusão entre os dois fenômenos religiosos distintos. Muitos xamanismos indígenas são menos tradicionais do que pensam, tendo sido concebidos recentemente sob a influência externa.

Por outro lado, vários pesquisadores acadêmicos consideram o neoxamanismo como 'uma moda cultural da nova era', um produto artificial da sociedade de consumo menosprezando o fato dele representar uma forma de espiritualidade contemporânea global viva e em crescimento exponencial. Daí a

o conceito, corroborado por McRae (1992), do Santo Daime como um 'xamanismo coletivo', em que todos são "xamãs em potencial". Cemin (1998) considera o Santo Daime como sistema xamânico, mas apenas o Alto Santo e não 0 CEFLURIS, porque neste último há transes de incorporação. Para Groisman, o Santo Daime não é sistema xamânico, mas há uma aglutinação do saber xamânico nesta religião (1999, p. 23). 


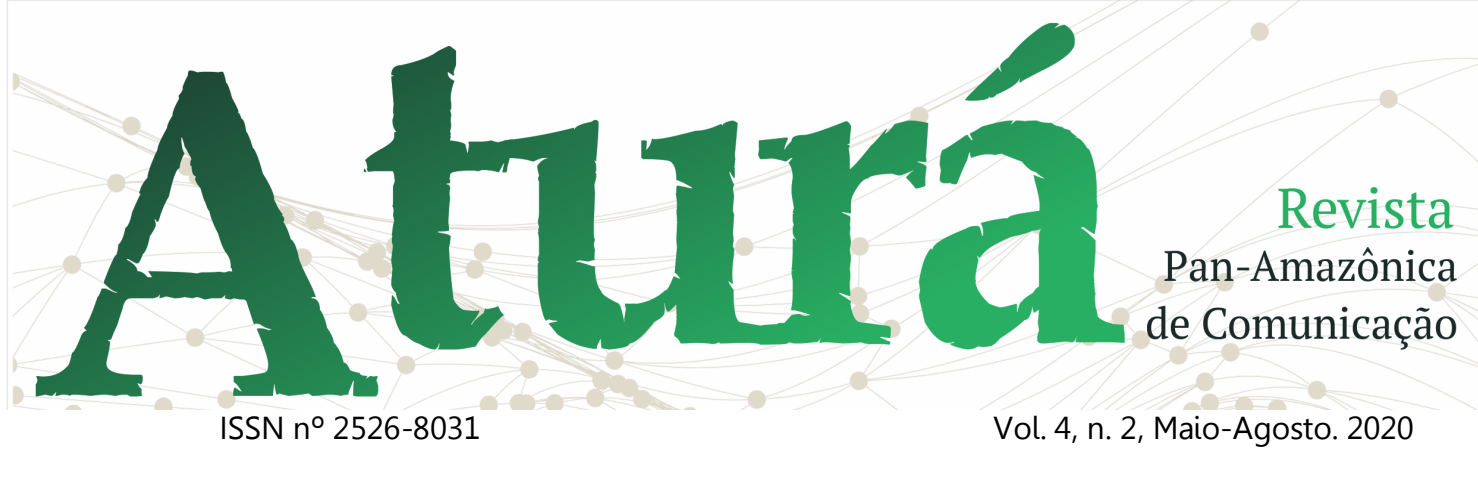

DOI: http://dx.doi.org/10.20873/uft.2526-8031.2020v4n2p121

importância premente de se ressaltar as diferenças e de se repensar as semelhanças entre os diferentes tipos de 'xamanismos'.

\section{Comparando o passado e o presente}

Por exemplo, enquanto 'todos são xamãs quando despertos' no neoxamanismo, o recrutamento dos antigos xamãs combinava a transmissão hereditária da profissão com a vocação espontânea do pretendente. Havia um 'chamado' da natureza e uma 'escolha' a ser feita por quem era chamado. A confirmação, segundo Eliade, era dada pelo transe - mesmo que a criança nascesse com marcas ou sinais característicos dos xamãs ou houvesse algum oráculo a respeito. Na verdade, a própria intensidade da experiência extática excluía severamente a criança do convívio da comunidade e era decisiva para determinar sua vocação xamânica. $\mathrm{E}$ o inverso também acontecia: uma criança sem família e/ou com problemas de adaptação grupal acabava desenvolvendo 0 transe e se tornava xamã. Em ambos os casos, no entanto, o transe é causa e consequência de um comportamento de um desajuste psicossocial. Eliade gasta algumas páginas explicando as diferenças entre o transe extático e os ataques epilépticos e outros distúrbios nervosos (2002, 37-47).

Atualmente, o transe está sendo substituído gradativamente pela mediunidade espírita ${ }^{4}$ e pelo uso de plantas de poder. Houve também uma democratização da experiência de canalização, antes uma prerrogativa do xamã, hoje partilhada pelos participantes.

O importante é perceber que 0 recrutamento, o treinamento e a outorga de poderes xamânicos eram conferidos a indivíduos desajustados e socialmente excluídos, que por algum motivo não

\footnotetext{
4 Um dos requisitos do transe genuinamente xamânico é que ele não é uma possessão ou uma incorporação. São os xamãs que manipulam os espíritos e não o contrário. Devido a isso, a umbanda, o catimbó e outras formas de espiritismo popular não são consideradas 'xamanismo'.
} 


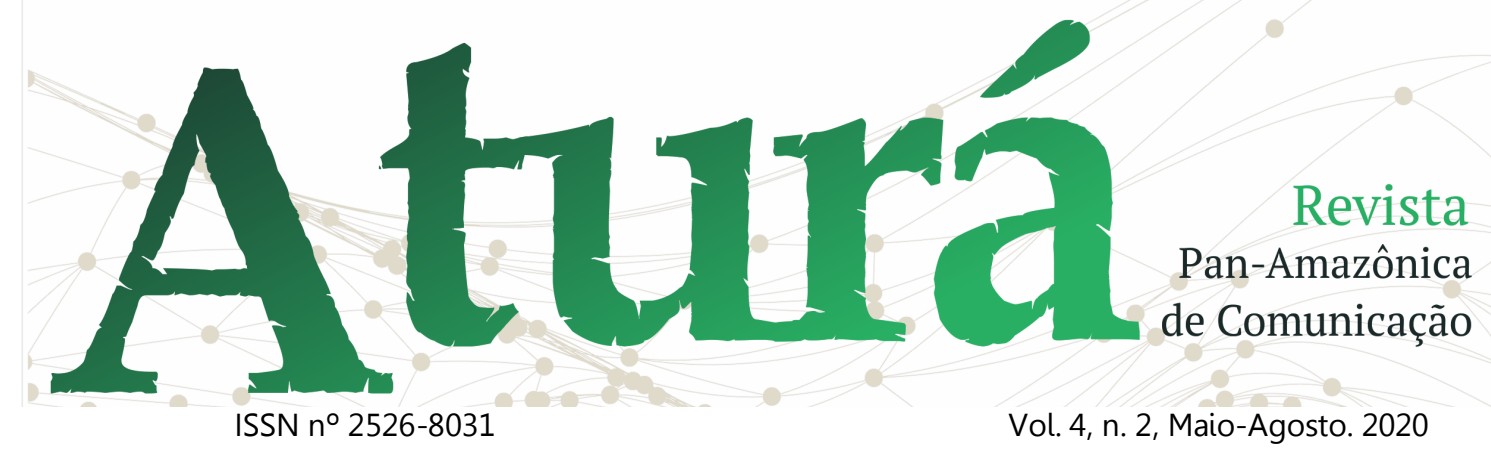

DOI: http://dx.doi.org/10.20873/uft.2526-8031.2020v4n2p121

suportavam a vida familiar e grupal, em um regime de disciplina intenso que prescrevia, não apenas dietas e rituais, mas sobretudo isolamento e autocontrole. Os antigos xamãs eram assim indivíduos circunspectos e solitários, que geralmente não casavam e viviam à margem de seu grupo social. Hoje, o processo de recrutamento, seleção social e treinamento prático de xamãs não obedece mais a esses rigores devido a uma mudança de contexto cultural. A antiga disciplina pode até ser simulada em detalhes (como no caso da 'busca da visão', dos índios norteamericanos, atualmente transformada em jornada de autoconhecimento), mas não terá o mesmo sentido social.

Outra diferença marcante entre os xamanismos arcaicos e o neoxamanismo urbano reside no fato de que, enquanto esse último pretende sensibilizar as pessoas; os xamanismos antigos enfatizarem 0 descondicionamento social e biológico, "perder a forma humana". O neoxamanismo deseja ser mais humano (no sentido adjetivo ${ }^{5}$ ); os xamanismos arcaicos intentam ser menos humanos (no sentido substantivo). Porém indiferentes a essa colocação, muitos grupos de neoxamanismo entendem os animais de poder como se fossem símbolos que caracterizam aqueles com as quais estão associados, como signos astrológicos ou orixás do candomblé6, e não como um

\footnotetext{
${ }^{5}$ Segundo Castaneda, "abandonar o molde humano' (ou romper com o condicionamento biológico) significava, para os antigos videntes, conhecer seu animal totêmico de poder, adotando outra forma nos sonhos". Para ele, atualmente, a perda da forma humana é marcada pela percepção de si como um campo de energia ou como um 'ovo luminoso'.

6 Ressalte-se que nem a astrologia nem o candomblé eram tipológicos em suas versões originais. Na África antiga, quando se nascia nas praias, se era filho de Yemanjá; se nas montanhas, de Xangô; e assim por diante. Os orixás eram ligados aos locais e não às pessoas individualmente. Por isso, eles eram passados de pai para filho. No Brasil, com a mistura das etnias, foi que surgiu o orixá como tipo psicológico individual e as referências simbólicas espaciais foram colocadas em segundo plano. Também na astrologia antiga não havia horóscopos individuais. As previsões eram meteorológicas e sobre guerras; e o mesmo o oráculo dos reis não era voltado sua vida pessoal, mas para seu reinado. Hoje vários tipos de simbologias tradicionais sobrevivem através de tipologias psicológicas: os quatro elementos, signos astrológicos chineses, kins do calendário maia, o eneagrama.
} 


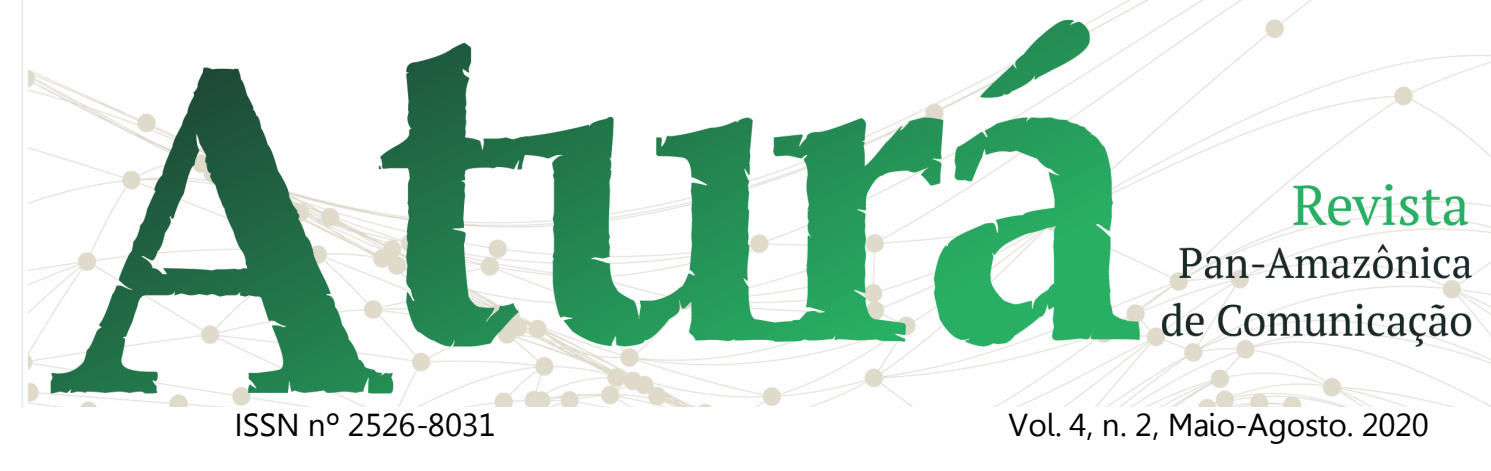

DOI: http://dx.doi.org/10.20873/uft.2526-8031.2020v4n2p121

marco de transformação nos padrões cotidianos de comportamento instintivo e emocional humanos - conquistados através da iniciação e de uma vida de restrições e sacrifícios. O neoxamanismo em geral, porém, prefere valorizar as vontades do corpo e os sentimentos do coração para compensar "nosso racionalismo patriarcal".

E a questão chave da desanimalização não é o controle individual dos desejos e instintos, mas o comportamento em relação ao seu grupo. Ao estudar os rebanhos mamíferos, Kurt Lewin (1989) observou três comportamentos recorrentes: identificação (eu sou o poder), contestação (eu sou contra o poder) e submissão (aceito o poder como algo fora de mim). Gomes (2001), associa os que se identificam com o poder à categoria de Pastores; os contestadores foram definidos como Lobos; e os submissos denominados de Ovelhas. $O$ Pastor é o macho-alfa, gerente do capital do grupo; enquanto, o Lobo é o xamã por excelência, aquele que expressa o inconsciente grupal.

Assim, um grupo é (mais e menos que) a soma dos seus componentes. O trabalho coletivo é mais que a soma dos trabalhos individuais gerando um excedente, o resto que sobra do todo menos as partes (o Capital). Porém, o grupo também é menos que a soma das suas partes e recalca as qualidades de seus componentes. A esse déficit inibido das partes através do todo, chamamos inconsciente grupal. (GOMES, 2013, 13).

Embora existam casos, como o de Gengis Khan, em que o xamã é também o líder do grupo (Lobo e Pastor, ao mesmo tempo), o mais comum é que os dois papéis sejam distintos e polarizados (pelas Ovelhas). Deleuze e Guatarri (1980) elaboraram o termo 'espírito de matilha' em oposição ao 'espírito de rebanho' para caracterizar o comportamento de contestação e independência dos indivíduos parcialmente excluídos do condicionamento grupal, incluindo aí os xamãs; mas a desanimalização dos padrões grupais prescrita pelas técnicas arcaicas de êxtase é ainda mais radical, exigindo a morte do ego do iniciado e a 


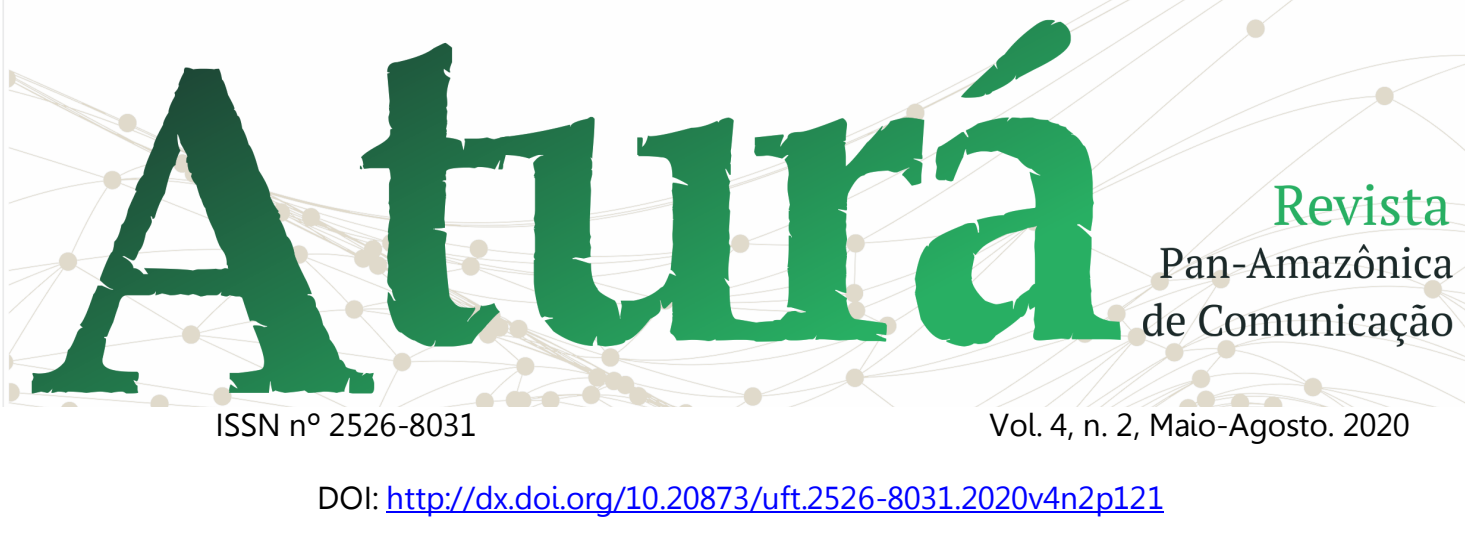

retomada teatral de suas funções na comunidade, superando o papel de Lobo do rebanho.

E a maioria dos grupos do neoxamanismo urbano (assim como outros grupos esotéricos atuais) não observam a existência das relações de poder (de dominação, contestação e submissão) em seu interior; e vive inadvertidamente pelas regras do rebanho, sem esperanças de desanimalização do condicionamento biológico e social a que está submetido. Seus xamãs são apenas Pastores disfarçados com pele de Lobo.

\begin{tabular}{|l|l|l|}
\hline O recrutamento & Xamanismos arcaicos & Neoxamanismo urbano \\
\hline $\begin{array}{l}\text { vocação espontânea (chamado } \\
+ \text { escolha) }\end{array}$ & $\begin{array}{l}\text { Todos podem ser xamã, basta ser } \\
\text { despertado }\end{array}$ \\
\hline O transe & $\begin{array}{l}\text { Diferenças com a } \\
\text { psicopatologia }\end{array}$ & Mediunidade e plantas de poder \\
\hline A desanimalização & Abandonar a forma humana & Ser mais afetivo e instintivo \\
\hline O rebanho & O espírito de matilha & O neoxamã é um pastor \\
\hline
\end{tabular}

encantamento do mundo, mas esse não é o caso. Se ressaltamos a incapacidade do

\section{Gnóstico vs. pós-moderno}

Pode parecer ao leitor que aqui também se deprecia as manifestações culturais mais recentes em nome das mais antigas, com saudades do neoxamanismo de entender suas raízes arcaicas é apenas para melhor enquadrálo e compreendê-lo historicamente. 


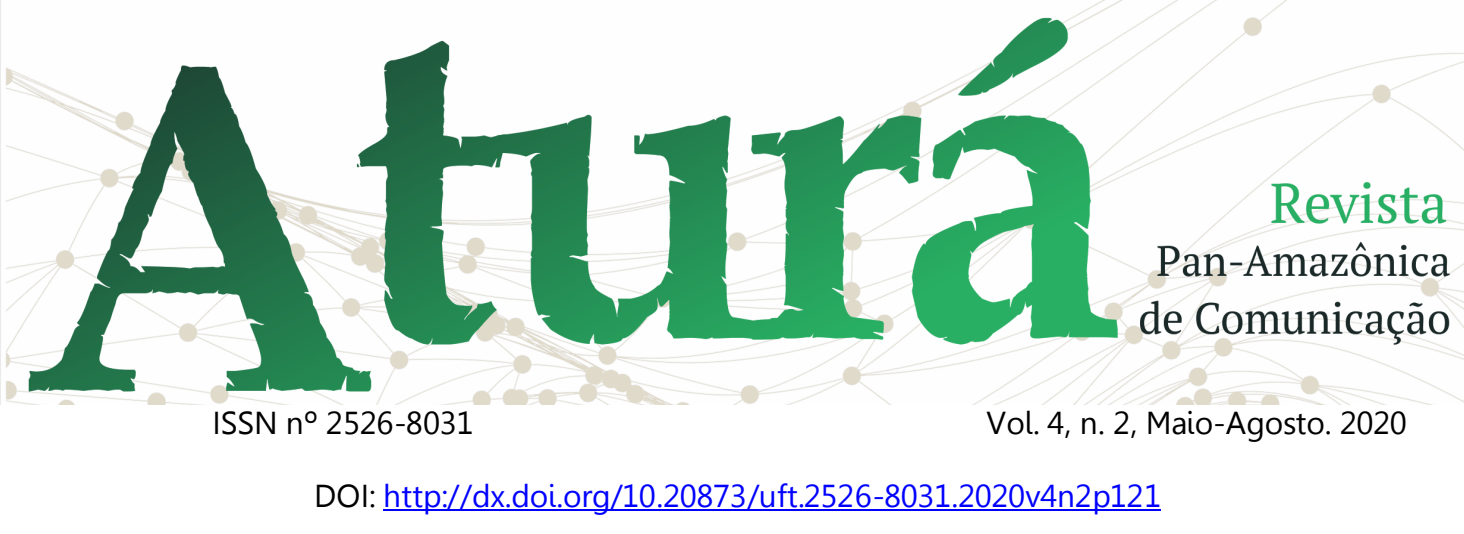

Existem muitas outras diferenças de contexto e de propósito (além do recrutamento, do transe e da

desanimalização) entre os antigos xamanismos e o neoxamanismo, algumas até mais favoráveis ao xamanismo atual. Por exemplo: no passado, os xamanismos eram, na sua maioria, masculinos; agora, são predominantemente femininos - não apenas em quantidade de participantes, mas, sobretudo, em suas práticas rituais e objetivos. Ou ainda: tanto o neoxamanismo quanto os xamanismos arcaicos dão ênfase à natureza, mas de formas diferentes. $O$ neoxamanismo trabalha mais com a ideia de meio ambiente e de consciência planetária. Castaneda formula o interessantíssimo conceito de 'seres inorgânicos', formas de vida de outra escala de tempo que se alimentam dos homens e da vida orgânica. E tudo isso pode ser considerado um avanço em relação às antigas práticas e para um panteão de deuses arcaicos representando a mãe natureza.

Também destaque-se que, entre as formas atuais de neoxamanismo, há dois tipos polares: o neoxamanismo gnóstico, que vive em função de outro mundo e acredita em toda sorte de imagens e símbolos; e o 'xamanismo pós-moderno', que ignora a dimensão transpessoal da psique e considera que 'o além' é apenas ilusão ou ideologia das religiões institucionalizadas. $\mathrm{E}$, entre esses polos, há diversos tons de cinza. Mas, bem vistas toda essa diversidade atual e ainda as diferenças positivas e negativas entre passado e presente, há dois elementos universais: a) a cura pela transferência não-analítica como prática principal; e b) a transcendência dos sistemas de crenças.

A ênfase de converter negatividade em atividade positiva, de mediar os conflitos através de rituais simbólicos parece ser universal. É claro que o antigo xamã mediava o conflito entre forças das naturezas personalizadas em deuses; e hoje o neoxamã busca revelar o lado 


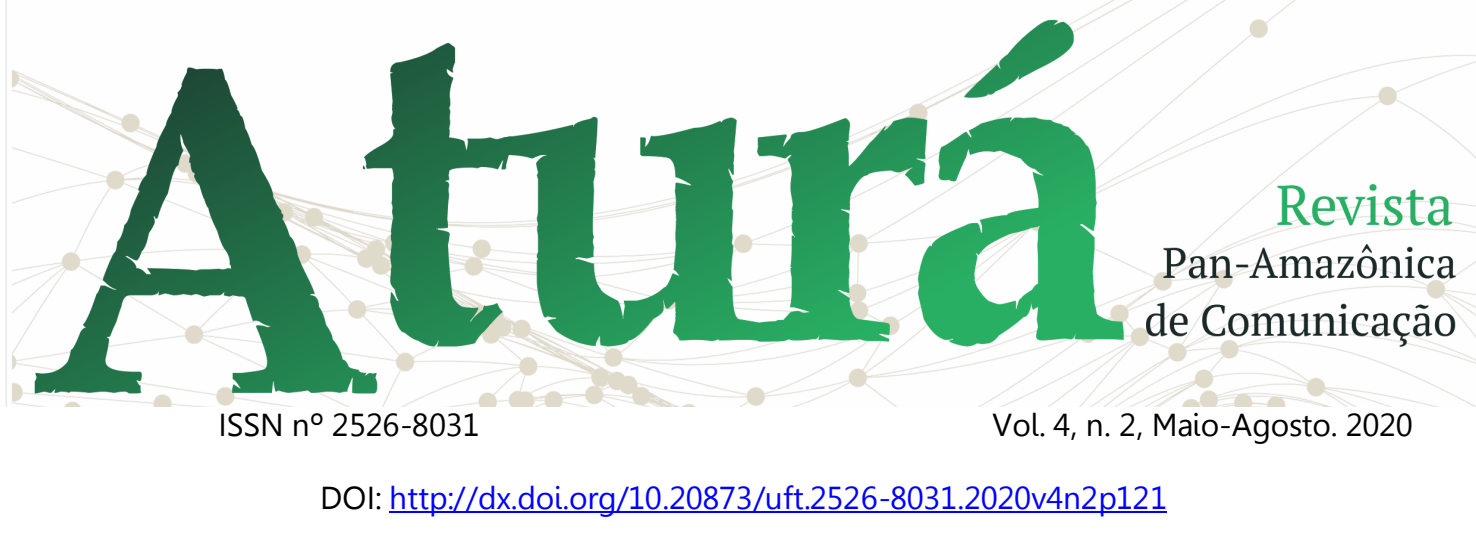

feminino dos homens em oposição ao lado masculino das mulheres. Mas, a técnica base continua a mesma: canalizar o negativo, compensá-lo com o oposto e devolver equilibrado. Os xamanismos e o neoxamanismo tem essa ênfase na prática da cura ou, se preferirem, nas relações de transferência e contratransferência não-analíticas de conteúdo simbólico.

Outra continuidade entre os antigos xamanismos e o neoxamanismo atual é que os primeiros são sistemas mágicos meta religiosos, um conjunto de práticas místicas, psicológicas e extáticas, anteriores e paralelas à elaboração dos grandes sistemas de crença religiosa. $O$ ceticismo, o pragmatismo, o empirismo avesso a transcendências - são características comuns de diferentes tipos de xamanismo no transcorrer do tempo. Eles são laicos e objetivos, sistematizações da experiência prática e não um conjunto de crenças, mágicas, anteriores aos sistemas de crenças religiosos.

Mas em paralelo a esse desencanto religioso, há também a afirmação viva do cotidiano como uma aventura extraordinária, povoado de mistérios e situações singulares. E o neoxamanismo, herdeiro destas práticas e dessa visão ecumênica e agnóstica, também embora de formas diferenciadas.

No neoxamanismo pós-moderno de Castaneda, esse desencanto e reencantado é individual e é chamado de 'ética do guerreiro'. O guerreiro deve aprender a agir por agir, sem esperança nem desespero, a dar o melhor de si sem esperar retribuição, a confiar sem crer, a viver deliberadamente através de desafios constantes, a sempre escolher o caminho de seu coração, entre outros preceitos. Porém, mais do que um simples código de conduta contra a auto importância e a auto piedade, a ética do guerreiro é uma configuração energética em que o praticante se alinha ao Intento, uma energia inteligente que pode treiná-lo e guiá-lo até seu salto para o infinito. $O$ caminho do guerreiro consiste sobretudo em acumular e redistribuir energia de 


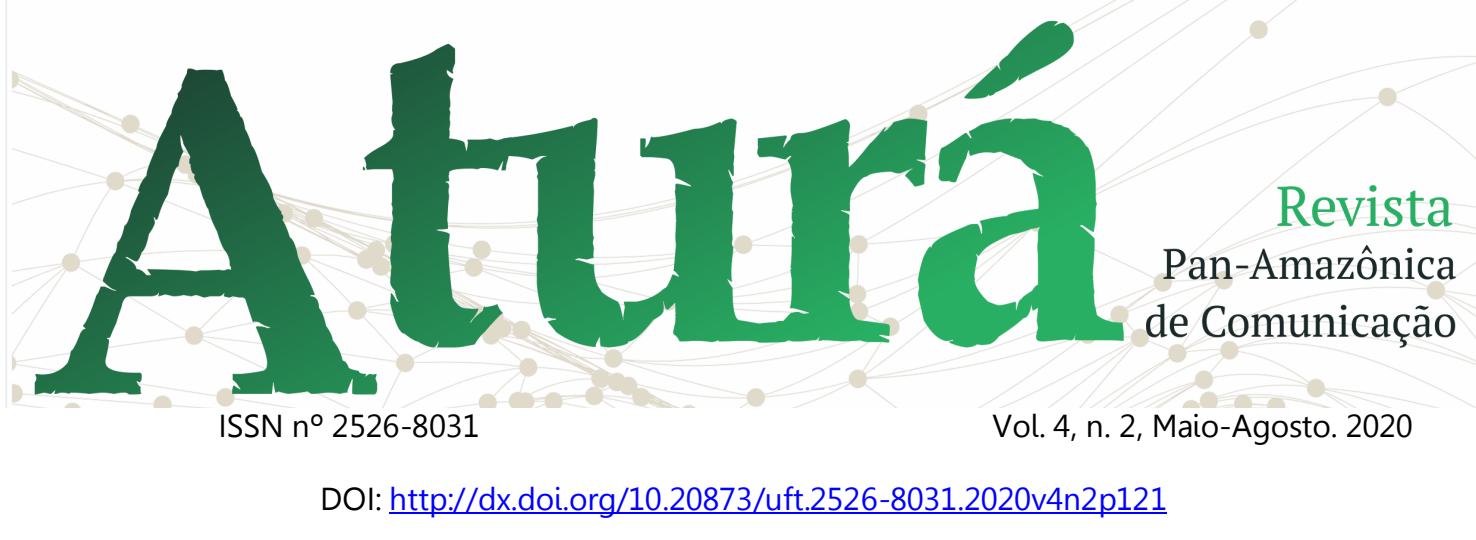

forma a sobreviver à morte e não ser absorvido pelos seres inorgânicos. Alcançar a 'liberdade total' significa sair da cadeia alimentar e não ser devorado dos predadores.

Não há rituais, imagens, indumentárias indígenas ou quaisquer elementos do 'complexo xamânico' proposto por Eliade. Ao contrário, Castaneda prescreve uma atitude de espreita, sobriedade e extrema discrição, despindo o xamanismo de todo seu simbolismo para enfatizar $\circ$ que considerava principal: a construção de um 'corpo sonhador' para escapar dos predadores inorgânicos e sair deste universo do carbono.

Já para o neoxamanismo gnóstico, o reencantamento do mundo é coletivo: os xamãs devem lutar pela mudança do 'sonho planetário'. Para don Miguel Ruiz (2005), por exemplo, há dois sonhos coletivos em desenvolvimento: o sonho que chamamos de realidade - "o tonal, a primeira atenção, sonho do inferno ou o sonho da vítimas" - e o sonho dos guerreiros, um sonho alternativo de realidade - "o nagual, o sonho da segunda atenção".

Para Ruiz, o sistema de crenças é uma estrutura parasita de energia. Sonhamos um sonho coletivo que nos aliena da vida e nos mantêm em uma realidade virtual, uma 'Matrix' formada por nossas crenças e valores. Segundo ele, é libertar nosso sonho pessoal do sonho coletivo do medo de exclusão, do sonho de domesticação social engendrado pela sociedade; $\mathrm{e}$, em conjunto com outros sonhadores conscientes, transformar esse sonho social de destruição planetária, induzindo toda humanidade a um salto quântico evolutivo. Para os xamanismos, o sonhar é a base de toda experiência cognitiva: estamos sonhando o tempo todo, seja dormindo ou quando estamos acordados. A diferença é o enquadramento mentalsensorial no estado de vigília (ou tonal) da percepção da energia (ou nagual).

\section{A simetria cognitiva}




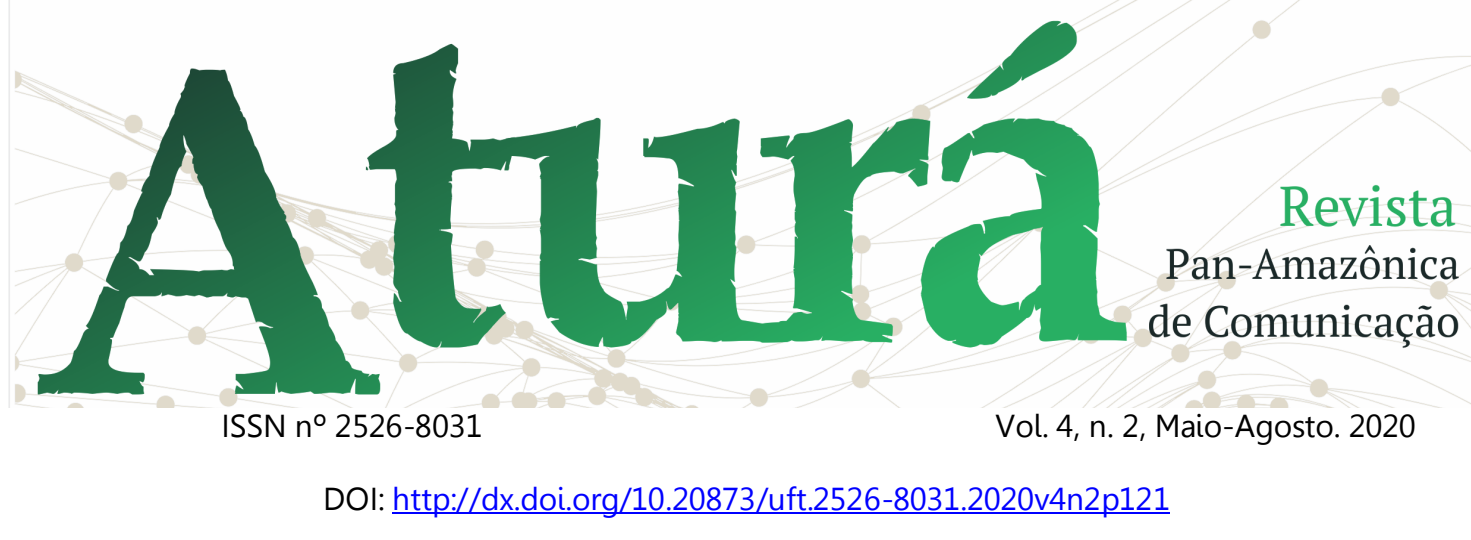

Há sempre uma dupla realidade, uma simetria entre o lado de dentro e o de fora, o micro e o macrocosmo. No campo filosófico há, para Platão, um mundo sensível-concreto e outro inteligível-abstrato; uma cidade dos homens e uma cidade de Deus para Santo Agostinho; para Descartes, coisas extensas e objetos virtuais. Com Kant, há uma inversão de perspectiva: a realidade deixa de ser uma percepção e passa a ser uma interpretação. $O$ mundo externo se torna uma projeção estruturada do sujeito, a simetria torna-se um reflexo invertido.

No campo religioso também há simetria, mas é o metafísico que se reflete no físico: "assim em cima, como embaixo" - expressão presente não apenas nas Tábuas de Esmeralda de Hermes Trimegisto, mas presente em todas as grandes tradições, como a chinesa (céu e a terra), a indiana (o universo-templo e o corpo-templo), e a ocidental (o homem como a imagem e semelhança de Deus). No humanismo iluminista, há cruzamento desses dois modos de representação

simétricos, o filosófico e o tradicional, em que o homem ocupa o lugar central (como na tradição judaico cristã), mas o universo externo que enquadra e determina a experiência subjetiva (como crê a modernidade).

Para as tradições, a simetria é dada como certa (o mundo material é um desdobramento denso dos universos sutis); para modernidade, a simetria é parcial e invertida (o subjetivo parcialmente reflete a realidade total); para o pensamento pós-moderno (seja filosófico, antropológico ou esotérico), não há simetria ontológica (nem reflexividade entre dimensões paralelas): os objetos é que são duplos construídos intersubjetivamente em um único plano imanente bifacetado: como a onda e a partícula.

Os conceitos de Tonal e Nagual representam campos perceptivos opostos e complementares, em que o primeiro é nossa percepção ordinária (sensorialmental) do mundo como algo formado por objetos concretos e coisas sólidas; e o 


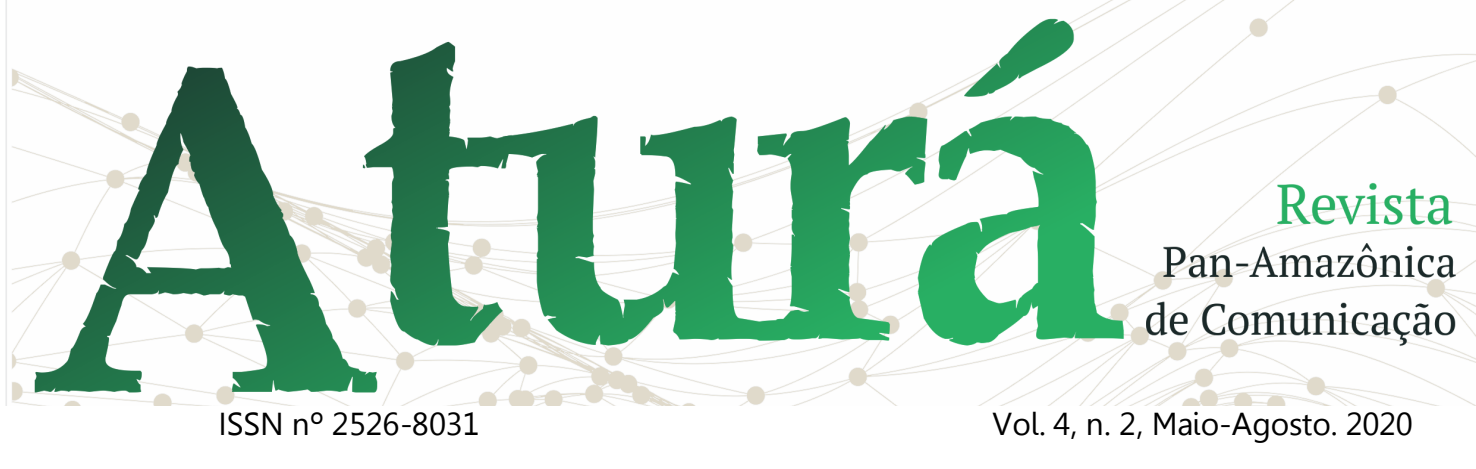

DOI: http://dx.doi.org/10.20873/uft.2526-8031.2020v4n2p121

último é a percepção de que estamos em um universo de relações, em que tudo é feito de energia em diferentes níveis de organização e de adaptação. Mas, há também duas interpretações dessa polaridade cognitiva básica. Ruiz (o gnóstico) entende a tarefa do xamã em uma dimensão social: o sonho coletivo do medo só poderá ser transformado com grande número de sonhadores que desejem a liberdade pessoal. Ruiz acredita poder romper com o sonho social de medo tecendo um novo sonho. Para Castaneda (o pós-moderno), o tonal é uma ilha (ou bolha da percepção) e o nagual a um oceano-universo que $O$ engloba: o mar escuro da consciência. A vida orgânica (o tonal) é uma gota em um universo inorgânico. A tarefa do xamã é sair individualmente do seu ovo tonal e viver em um universo nagual, deixando para trás a condição humana. Enquanto um sonha em salvar o planeta e a humanidade, o outro intenta antes salvarse do destino humano de ser absorvido pela terra.
Assim como a antropologia pósestruturalista entende a realidade como uma sobreposição das dimensões sensíveis e inteligíveis e não é antropocêntrica; o xamanismo recusa a ideia de semelhança entre o homem e o universo; e a dicotomia transcendentalista da caverna de Platão. Ele prefere entender o homem dentro da cadeia alimentar no meio ambiente e concentram seus esforços na descondicionamento dos hábitos e rotinas, na desmecanização do corpo e no desenvolvimento da consciência. Nessa perspectiva, a simetria entre a cognição ordinária e a extraordinária está além do homem e é um paradoxo insuperável para o qual não existe totalização ou unificação globalizante. 0 Mundo e a Consciência são termos irredutíveis?.

\footnotetext{
${ }^{7}$ É conhecida a prescrição de Carlos Castaneda de que seus aprendizes deveriam estudar antropologia. Florinda Donner, Taisha Abelar, Armando Torres - entre outros tiveram que estudar ciências sociais na UCLA para se tornarem feiticeiros. É possível que a prescrição antropológica de Castaneda seja uma garantia anti-gnóstica, uma forma de fortalecer o tonal e
} 


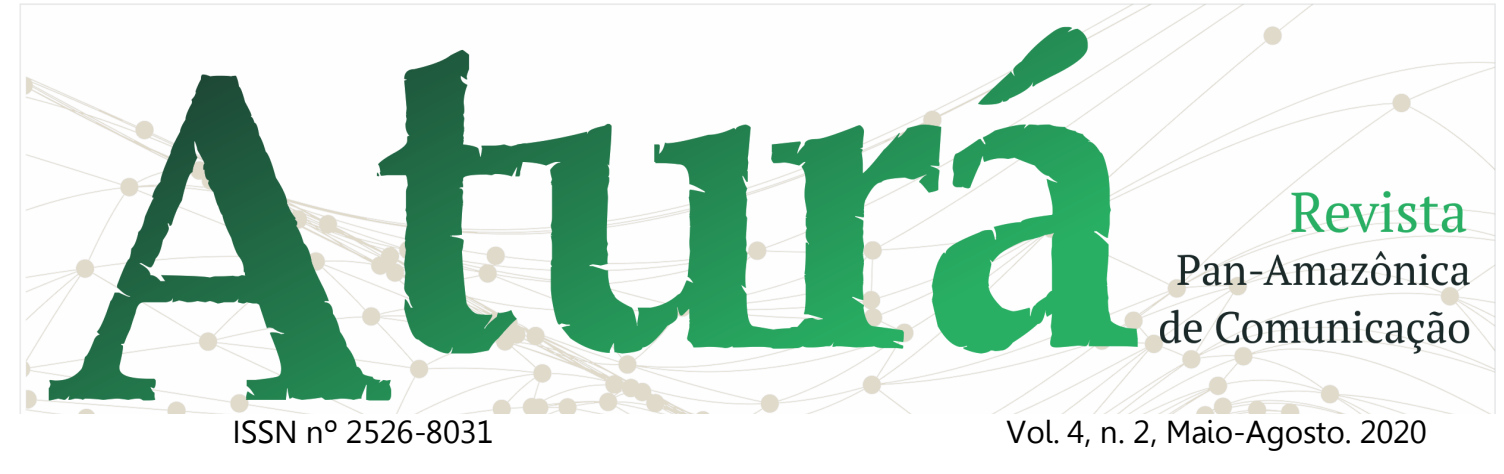

DOI: http://dx.doi.org/10.20873/uft.2526-8031.2020v4n2p121

\section{Princípios da Feitiçaria Midiática}

(...) A magia em suas formas mais primitivas é normalmente designada como "arte". Acho que isso é bastante literal. Eu acredito que a magia é arte e que a arte, quer por escrito, música, escultura ou qualquer outro meio é literalmente mágica. A arte é, como mágica, a ciência de manipular símbolos, palavras ou imagens para realizar mudanças na consciência. Conjurar um encantamento é somente encantar, manipular palavras para mudar a consciência das pessoas. Então eu acho que um artista ou escritor é a coisa mais próxima que você vai ter de um xamã no mundo contemporâneo.

(...) $O$ fato de que agora esse poder mágico degenerou $o$ nível de entretenimento barato e manipulação é uma tragédia. Atualmente, aqueles que utilizam xamanismo e magia a moldar a nossa cultura são os anunciantes. Ao invés de acordar as pessoas xamanismo é a droga usada para tranquilizar as pessoas, para torná-las mais manejáveis. A sua caixa mágica da televisão, com as palavras mágicas, seus slogans, pode fazer com que todos no país pensam nas mesmas palavras e tenham os mesmos pensamentos banais exatamente ao mesmo tempo. The Alan Moore Mindscape (2003, 23:43 - 32:37).

manter a mente dentro da realidade objetiva, sem ilusões transcendentes.
A hipnose como arte é uma atividade coletiva muito antiga; ela acontece entre grupos sociais e através de instituições; ela comunidades de afeto dentro de uma sociedade estruturada. Ninguém sabe ao certo quando começou ou por quem foi criada.

Digamos logo de saída e sem arrodeio: enuncia-se aqui a seguir quatro princípios da feitiçaria midiática, amplamente utilizados e escondidos pela publicidade contemporânea. Depois, explicamos melhor os fundamentos e as consequências desses princípios. São eles:

I. Princípio da Singularidade Artesanal. Em oposição à noção de reprodutividade técnica de Benjamim, a dessacralização da arte pela produção em série promovida pela industrialização de todos os objetos da sociedade ${ }^{8}$; enunciase aqui o princípio da singularidade técnica, em que o objeto único e original, manualmente produzido sem cópias é uma forma de arte. $\mathrm{Na}$ sociedade

\footnotetext{
${ }^{8}$ A Obra de Arte na era de sua reprodutividade técnica $(1983,5-28)$ Benjamin ressalta o impacto que a produção em série de objetos pela indústria teve sobre a percepção. A obra de arte era única no tempo e no espaço e isso the conferia uma áurea, uma presença sagrada. Hoje praticamente tudo é reproduzido de modo idêntico. A arte, então, deixou de ser sagrada, 'objeto de culto' para se tornar expressiva dos sentimentos e crítica da injustiça social.
} 


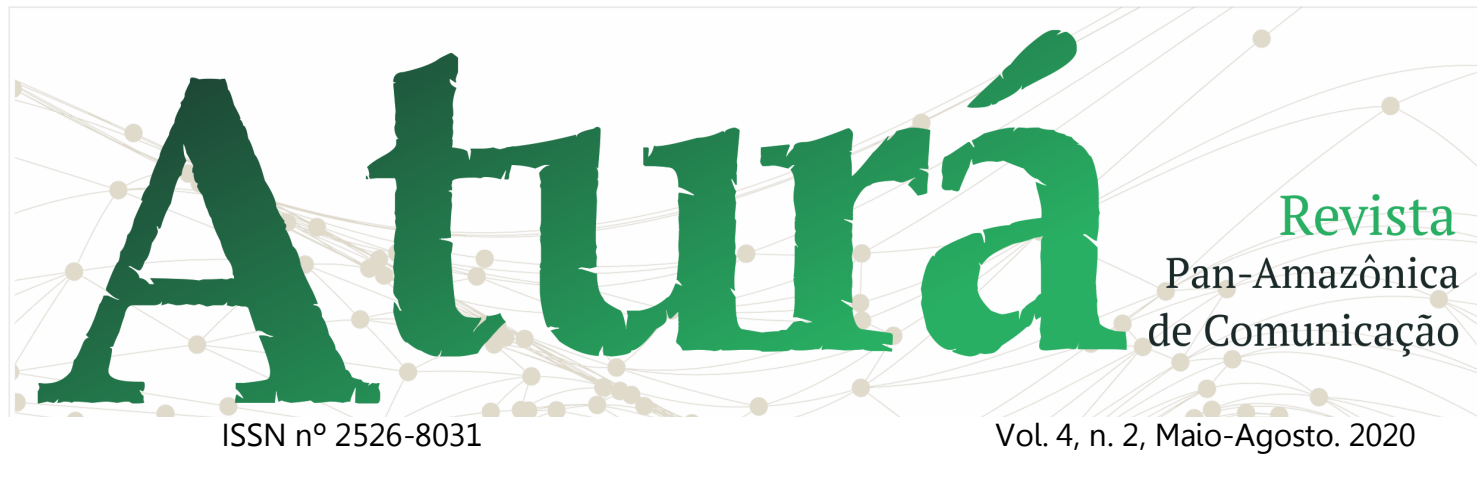

DOI: http://dx.doi.org/10.20873/uft.2526-8031.2020v4n2p121

industrial, todo objeto artesanal é um talismã da diferença, uma exceção no deserto da uniformização serial da objetividade. O objeto mágico é aquele que não tem cópia.

II. Princípio da Propagação da artesanal e único, mas sua imagem pode ser reproduzida ao infinito pela indústria cultural, aumentando significativamente seu poder. Todos o desejam, mas ele é apenas um. $\mathrm{O}$ encantamento do amuleto se propaga. Da união da cobiça das massas com a singularidade do objeto desejado forma-se uma assimetria unilateral daquele conceito com um público não presencial. A midiatização da singularidade universaliza a imagem do objeto no espaço e no tempo. O objeto mágico tem uma imagem icônica multiplicada ao infinito.

III. Princípio da Associação Narrativa. O objeto artesanal artificialmente propagado precisa ainda ser alimentado por imagens, sentimentos, alimentos e energia. O objeto mágico se nutre de narrativas simbólicas e factuais. $E$ seu poder deriva diretamente de sua presença nessas narrativas. Aliás, o objeto torna-se mágico através de uma narrativa, associando-o a uma ideia indicando a superação simbólica de vários opostos geralmente irreconciliáveis: sujeito/objeto, natureza/sociedade, vida/morte. O objeto mágico é também um índice, uma associação narrativa entre contradições simbólicas e acontecimentos.

IV. Princípio da Identificação Absoluta: A ubiquidade: não há mais diferença entre o objeto mágico e sua imagem serializada e propagada ao infinito. É o próprio objeto que está presente (e não sua reprodução ou cópia) em todos os lugares e tempos. É a fusão entre ator e personagem, entre jogador e avatar, entre médium e orixá. O objeto mágico é um deus encarnado em nosso universo. E a identidade de contexto e o universo narrativo através do qual o observador se observa: o paradigma. A imagem invertida do universo dentro de cada um.

Reza a lenda que a palavra francesa 'fétiche', tradução recente da palavra portuguesa 'feitiço', foi utilizada por engano na tradução de uma etnografia para o alemão sobre os povos da África ocidental. E antes que esse "mal entendido" fosse percebido a noção de fetiche já havia sido utilizada pelos maiores materialistas modernos (Karl Marx e Sigmund Freud). Por um lado, como ninguém sabe ao certo os nomes do autor e do texto, os antropólogos procuram, em vão, outras explicações para a etimologia dessas palavras (PIRES, 2009) e suas curiosas interpretações. Por outro, a própria origem das palavras (do latim facticius: "artificial, fictício") sugere um engodo, em que uma realidade só se sustenta enquanto houver crença em sua veracidade. Há mistério e encantamento nos próprios termos e em sua história. 


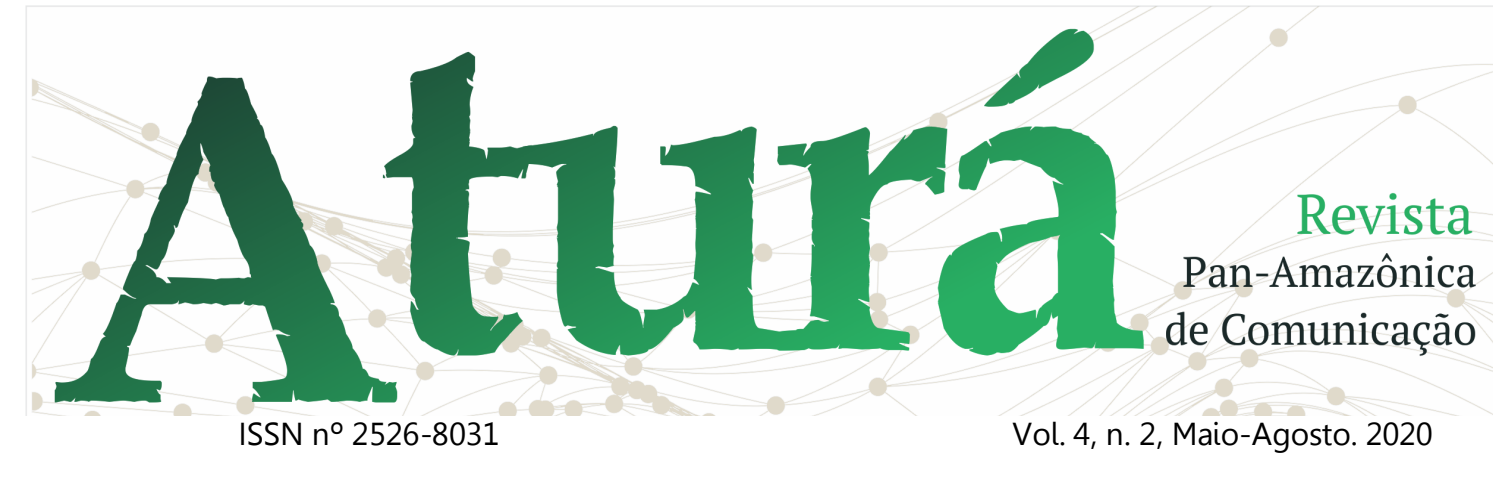

DOI: http://dx.doi.org/10.20873/uft.2526-8031.2020v4n2p121

Segundo o Dicionário Etimológico

Nova Fronteira da Língua Portuguesa, de Antônio Geraldo da Cunha, [...]

[...] "depois de ter contribuído, portanto, para a criação da palavra francesa fetiche, o português recorre ao francês para tomar-lhe emprestado o termo fetiche, que tem traços semânticos que a aproximam de feitiço, mas desta se diferencia por necessidade de especialização semântica". (1986, pág. 623)

O feitiço é, geralmente, um termo acusatório (algo reprovável feito por outros); enquanto o fetiche é uma espécie de obsessão pessoal por alguma coisa, uma situação, pessoa, ou parte da pessoa, uma atração ou fixação incontrolável que dá origem a um prazer intenso (nem sempre sexual). Por extensão também há equivalências e diferenças semelhantes entre os termos 'fetichismo' e 'feitiçaria'. Feitiçaria era, para Inquisição, a religião do Diabo.

O fetichismo, por sua vez, era, para os primeiros cientistas sociais, o sistema de crenças mágico, anterior às religiões institucionalizadas. Outras definições pensam a feitiçaria como um conjunto de práticas mágicas utilitárias (a mandinga); e o fetichismo como a crença em objetosdeuses. Já a feitiçaria ...

\begin{abstract}
Acho importante ter em conta três aspectos do problema do feitiço, todos eles revelando a sua ambiguidade. Primeiro, a ambiguidade entre construção e verdade: o feitiço poder ser falsificação e engano, mas existe a suspeita de que esse artifício, essa ficção, de fato seja verdadeira, que funcione, ou ainda, que tenha um "segredo", um "fundamento" que o acusador não conhece. Segundo: a ambiguidade entre acusador e acusado: o feitiço sempre é antes uma acusação do que uma prática auto definida; mas se reconhecendo como tal, o feiticeiro pode adquirir paradoxalmente poder sobre 0 acusador, o poder oculto da feitiçaria. Terceiro, e último, a ambiguidade entre sujeito e objeto do feitiço: a feitiçaria é uma arte da sedução e da sujeição, através da qual as pessoas se tornam objetos, ou, pelo contrário, os objetos podem ser vistos como pessoas. A feitiçaria é uma trama, que embrulha acusado e acusador, pessoas e objetos, verdade e ficção. (SANZI, 2009, pág. 128)
\end{abstract}

A feitiçaria, para os colonizadores portugueses, não era africana, arcaica ou tradicional; mas uma prática ordinária, universal, contemporânea e comum. Enquanto, o fetichismo é uma palavra europeia para designar uma prática religiosa africana. 


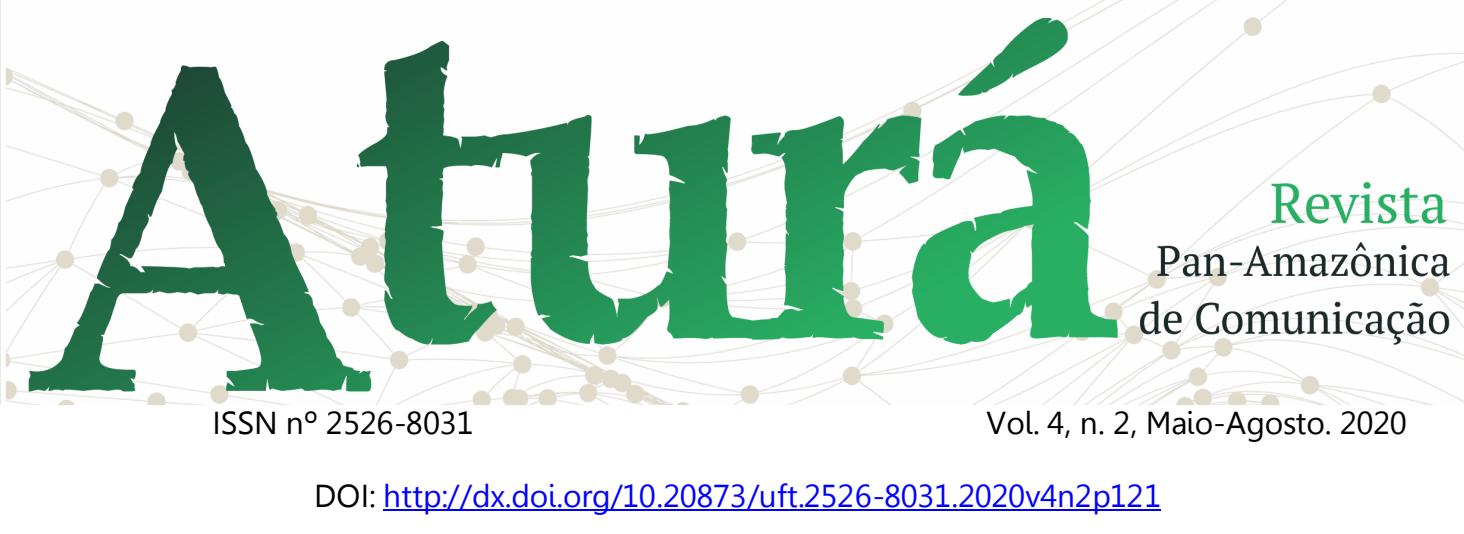

Hoje as palavras fetiche e

No âmbito da psicanálise, o fetichismo têm pelo menos quatro termo fetichismo é utilizado para definir o significados: a) o sentido psicanalítico (parte do corpo ou objeto que desperta excitação sexual); b) o sentido marxista (o mecanismo ideológico que transforma tudo em mercadoria); c) o sentido xamânico (um objeto enfeitiçado, amuleto ou ídolo; e d) o sentido figurado, o fetiche pode representar uma pessoa admirada por outra, que é seguida e cujas ordens são obedecidas cegamente.

$\mathrm{Na}$ verdade, cada sentido da palavra fetiche corresponde a um dos princípios midiáticos apresentados no começo. O fetiche sexual da psicanálise se explica pela áurea da singularidade. $O$ fetiche marxista é baseado na reprodução em série de condições de produção que excluem a maioria. O fetiche xamânico corresponde ao 'assentamento' do candomblé. E o sentido figurado ("fulano tem um fetiche por sicrano" - por exemplo) é análogo ao princípio da identidade. desvio do interesse sexual para algumas partes do corpo do parceiro, para alguma função fisiológica, para cenários ou locais inusitados, para fantasias de simulação ou para roupas e adornos.

Para Marx, o fetichismo é a lógica da mercadoria, um regime em que os homens se tornam objetos (mercadorias) e as coisas (os produtos) se comportam como pessoas. O fetichismo é uma relação social entre pessoas mediada por coisas, com a aparência de uma relação direta entre as coisas e não entre as pessoas. Disso resulta que a mercadoria (ou o mercado) parece determinar a vontade do produtor e não o contrário. $\mathrm{O}$ 'fetichismo da mercadoria' seria então a magia do capitalismo. Após Marx, outros retomaram a noção marxista de fetichismo, como Adorno; e Guy Debord (2000) mostrando que o fetiche de mercadoria e a coisificação do mundo, foi levado a um nível de objetividade muito além do que Marx imaginou. 


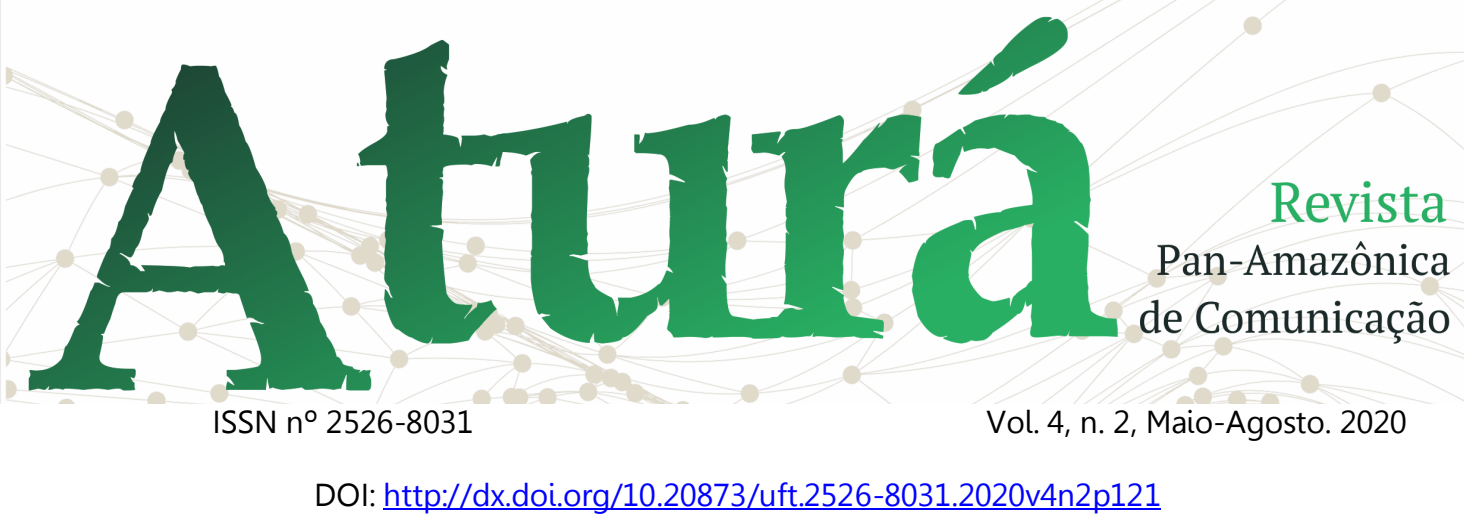

A história do fetichismo no sentido xamânico foi pesquisada por William Pietz, numa série de artigos titulados The Problem of the Fetish (1985, 1987, 1988 APUD SANZI, 2009). Nesta perspectiva, o objeto mágico é uma associação entre narrativas simbólicas e acontecimentos. Por exemplo: um fato natural (a chuva) em sincronia com acontecimento social (a alegria das plantas e pessoas do deserto) é uma narrativa que associa mudanças meteorológicas à comunidade de supostos sentimentos entre humanos e vegetais - tornando essa correspondência de interpretação universalmente verdadeira. O encantado é sempre uma associação entre o natural e o social, entre o sujeito e o objeto, entre o vivente e o extraordinário.

E a associação narrativa é sempre feita de coincidências crescentes e repetidos. A narrativa cria 0 encantamento, "uma intriga" entre dois lados com um final desejado. A narrativa é uma fabulação entre duas imagens e um desejo.
Para Michael Taussig (1993) e Bruno Latour (2002), leitores de Pietz, apesar da feitiçaria e do fetichismo terem sido descritos como parte das tradições pré-modernas em oposição à objetividade científica, na verdade, a objetividade da cultura moderna ocidental também é, em última instância, mágica e fetichista.

A modernidade é um encantamento macabro de identidade: a ilusão do observador externo. Durante a modernidade (esta imagem objetiva e coisificada que fazemos de nós mesmos), fomos prisioneiros da própria ilusão, forçados a sobreviver em mundo violento e sem sentido, jogados em um universo frio e sem alma, não passamos, aos olhos da ciência objetiva, de mamíferos tecno degenerados da crosta orgânica de uma bola de pedra girando em torno de uma bola de fogo.

Por outro lado, também não se pode retroceder, considerar os astros como são deuses e recolocar o observador como sujeito no centro do 


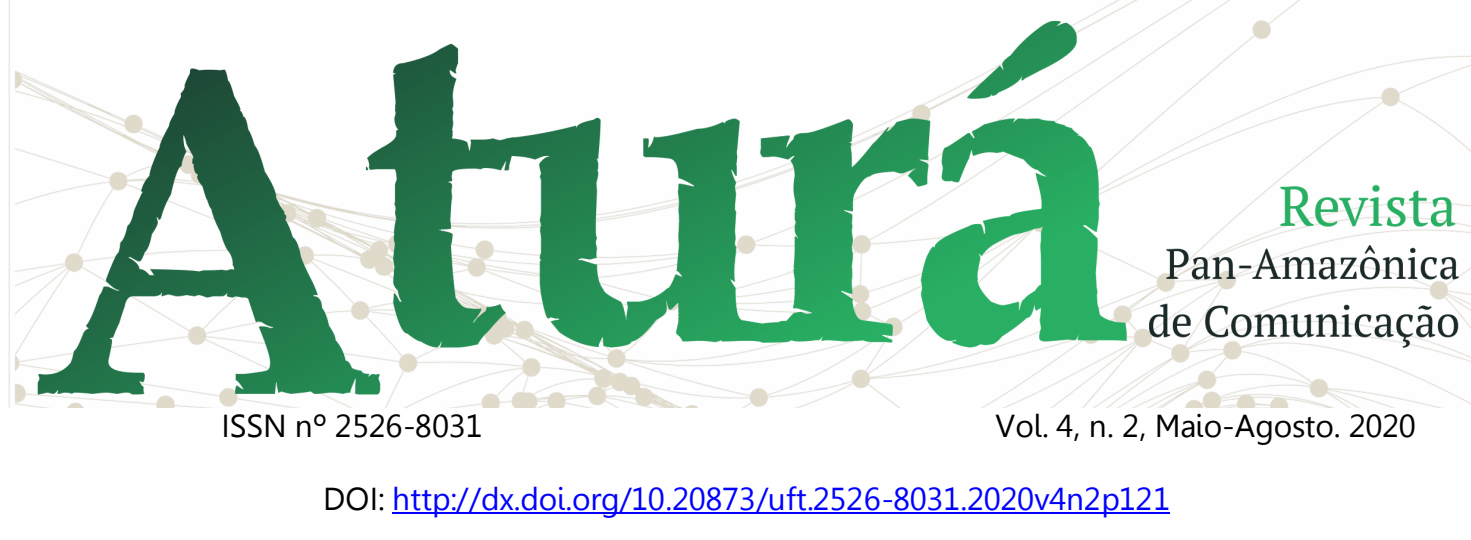

universo, como se fez antes da modernidade. É preciso perceber que universo é vibracional, constituído de energia e de relações entre diferentes estados de ser. Não há um único universo objetivo, mas vários universos virtuais (microcósmico, astrofísico, subatômico, etc).E, apesar da ciência contemporânea (a mecânica quântica, por exemplo) não ter mais objetos, ainda vivemos no mundo fetichista das coisas e não no universo reencantado das relações entre energias.

\section{E o que os feiticeiros pensam?}

Para Carlos Castaneda/don Juan Mathus, a Feitiçaria pode ser definida como a "arte de acumular e redistribuir energia com o propósito de escapar à segunda morte". A "antiga arte" seria um sistema mágico-cognitivo meta religioso, cético de todas as crenças, pragmático em relação à experiência empírica na mudança dos estados de percepção e terminantemente avesso a transcendências metafísicas ou representações das divindades.
A feitiçaria nessa definição é o oposto complementar do fetichismo, responsável pela organização do mundo ordinário e ilusório das coisas, sob o qual se percebe o reino das energias. Os fetiches (e a ilusão de que o mundo é formado por objetos) seriam formas de aprisionamento da atenção (e da energia) das pessoas para alguns aspectos da realidade em detrimentos de outros.

Antes a palavra fetiche resgatava a dignidade dos cultos africanos diante das acusações da Inquisição de feitiços. Hoje, a feitiçaria tornou-se libertária e deseja desencantar a modernidade fetichista. Confirma-se assim ironicamente o dito que sempre os feitiços se voltam contra os feiticeiros. Parece que o relógio do sonho de Descartes se tornou divino; que aqueles que lançaram o encantamento moderno ficaram hipnotizados em sua própria fantasia fetichista; e que agora os que podem romper com essa ilusão são justamente os que eram acusados de enganar pela magia. O desencantamento do mundo clama pelo reencantamento do universo. 


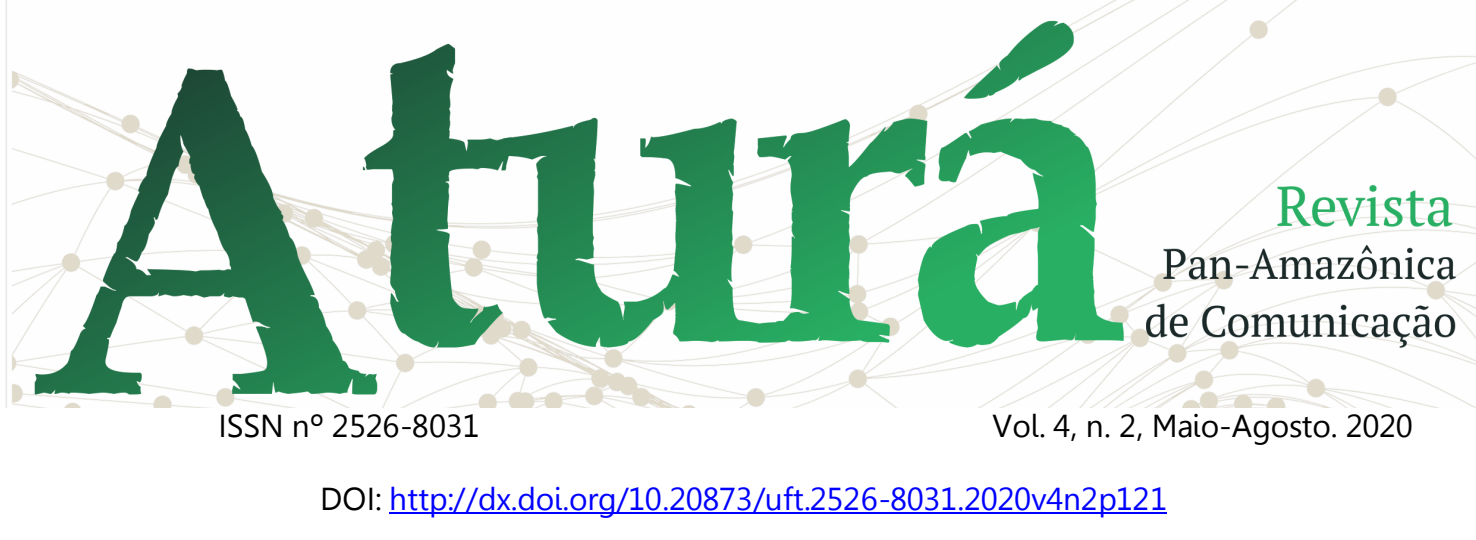

\section{Conclusão}

O sistema de xamanismo havaiano conhecido como Ho'oponopono é baseado nessas três operações transferenciais: Te amo; sou grato; e sinto muito-Me perdoe. Em Havaiano, Ho'o significa "causa", e ponopono quer dizer "perfeição", portanto Ho'oponopono significa "corrigir um erro" ou "tornar certo". O Ho'oponopono permite limpar recordações dolorosas, que são a causa de tudo que é tipo de desequilíbrios e doenças, com base nessas três operações: amar, agradecer e perdoar/ser perdoado.

\section{Quando uma pessoa doente} procura o xamã, o curador se identifica com seu paciente (eu te amo) adquirindo sua doença. $O$ xamã passa a partilhar da enfermidade para poder curá-la. O segundo passo consiste em fazer o paciente agradecer pela sua doença, entendê-la como uma mensagem do corpo para sua consciência que precisa ser decifrada. Caso consiga fazer com que o paciente agradeça sinceramente pela sua enfermidade, há 'a cura espiritual' e o xamã consegue libertar-se do karma da doença.

A 'cura material' ou completa só poderá ser alcançada através do perdão, isto é, de um reconhecimento de que foram seus próprios erros que formaram a doença e que isto prejudicou a outras pessoas além de si próprio. Este, aliás, é o propósito deste texto. Agradecer, perdoar e retribuir à dádiva com uma colaboração transformada e transformadora do presente original.

Obrigado, me desculpe, eu te amo.

\section{Referências}

AGOSTINHO, Santo. A Cidade de Deus, Tradução: Oscar Paes Leme. Ed. Vozes: Petrópolis, 1990.

BENJAMIM, Walter. A obra de arte na época de sua reprodutividade técnica. Obras Escolhidas (trad. S.P. Rouanet). São Paulo: Brasiliense, 1985.

BYSTRINA, I. Tópicos de Semiótica da Cultura. São Paulo: PUC/SP, 1995. 


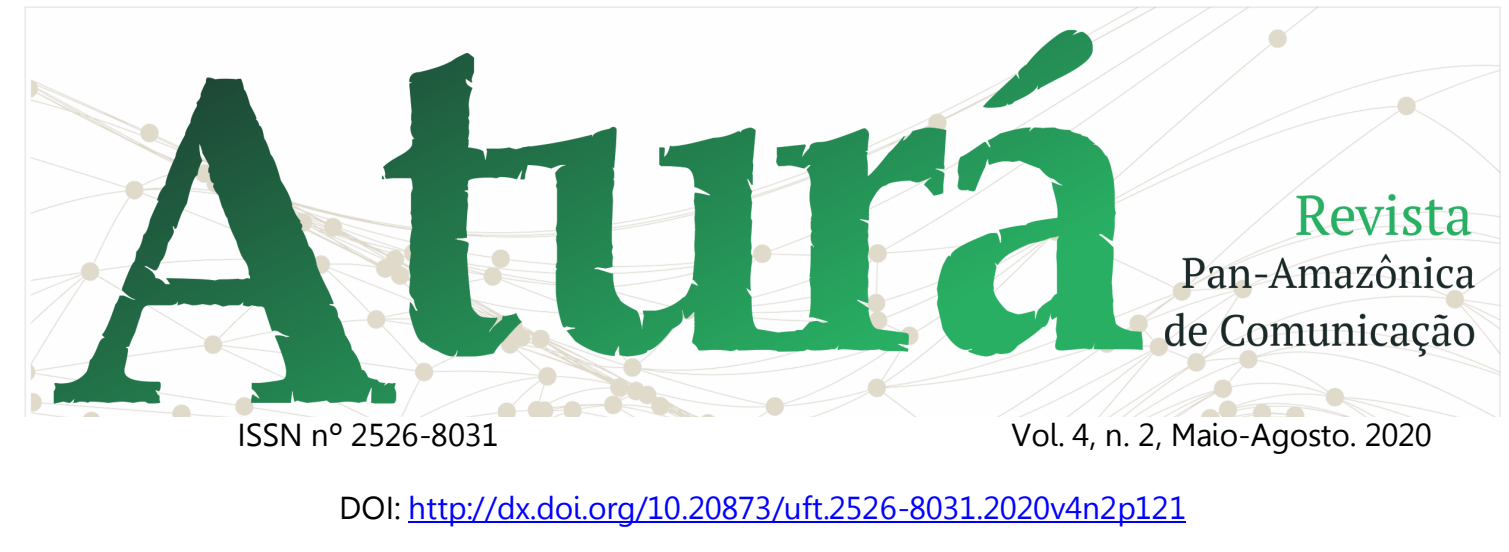

CAMPBELL, Joseph. O Herói de Mil Faces. São Paulo, Editora Cultrix/Pensamento, 1995.

LATOUR, Bruno. Reflexão sobre o culto moderno dos deuses fe(i)tiches. Florianópolis: Editora Edusc, 2002.

O Poder do Mito. Editora Palas Athena, São Paulo, 1990.

LEVI-STRAUSS. Claude. Anthropologia structurale. Paris: Plon/Agora, 1958.

COUTO, Fernando La Roque. Santos e Xamãs. Tese de Mestrado, UnB, BrasíliaDF, 1989.

ELIADE, Mircea. Tratado Histórico das Religiões. São Paulo: Martins Fontes, 1993.

O xamanismo e as técnicas arcaicas do êxtase. São Paulo: Martins Fontes, 2002.

FETICHE. In: FERREIRA, A.B. H. Dicionário Etimológico Nova Fronteira da Língua Portuguesa. Rio de Janeiro: Nova Fronteira, 1986. p. 623.

JUNG, C.G. Os arquétipos e o inconsciente coletivo. [tradução de Maria Luíza Appy e Dora Mariana R. Ferreira da Silva] Petrópolis: Vozes, 2002.

LATOUR, Bruno. Jamais fomos modernos: ensaio de antropologia simétrica. 2ed. Rio de Janeiro: Editora 34, 2009.

LEVI-STRAUSS, Claude. O pensamento selvagem. São Paulo: Ed. Nacional, 1976.

O cru e o cozido: Mitológicas I. São Paulo: Cosac Naify, 2004.

Do mel às cinzas: Mitológicas II. São Paulo: Cosac Naify, 2005.

A origem dos modos à mesa: Mitológicas III. São Paulo: Cosac Naify, 2006.

O Homem nú: Mitológica IV. São Paulo: Cosac Naify, 2011.

LEWIN, Kurt. Problemas de dinâmica de grupo. São Paulo: Cultrix. 1989.

MACRAE, Edward. Guiado pela Lua: Xamanismo e uso ritual da ayahuasca no 


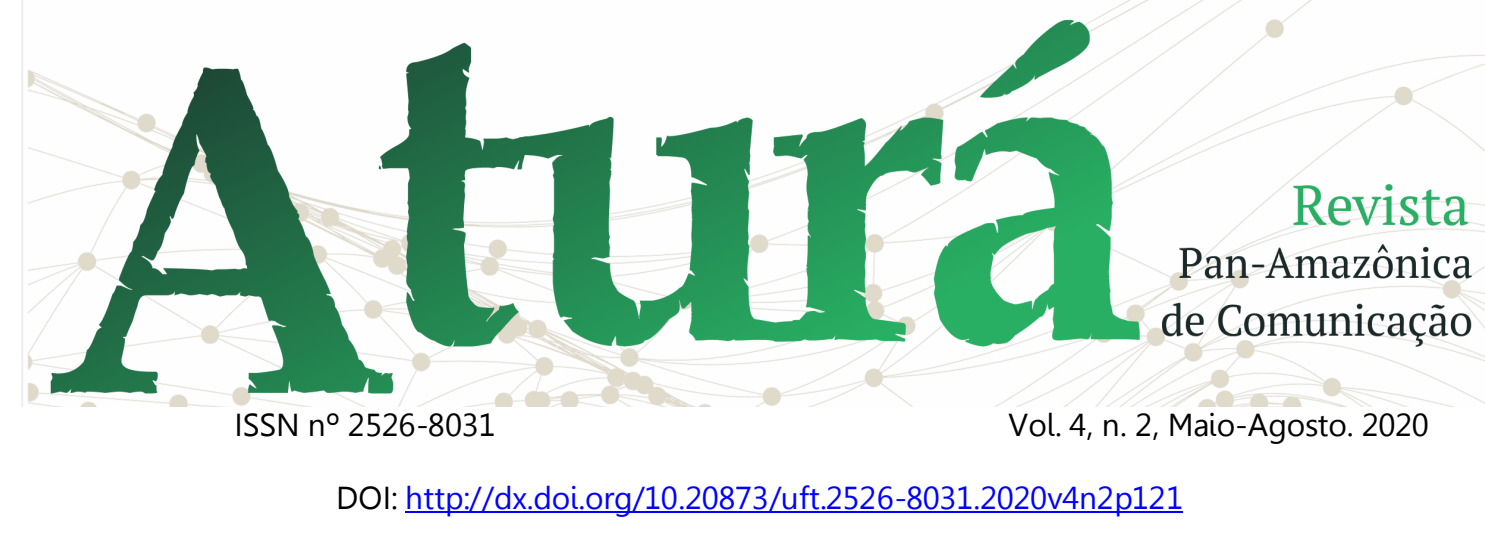

culto do Santo Daime. Editora Brasiliense, 1992.

RUIZ, Miguel. Os Quatro compromissos. Rio de Janeiro: Best Seller, 2005.

MAGNANI, José Guilherme Cantor. Mystica Urbe: um estudo antropológico sobre o circuito neo-esotérico na cidade. São Paulo: Studio Nobel, 1999a.

o xamanismo urbano e a religiosidade contemporânea. Religião e Sociedade, Rio de Janeiro 20 (2), 1999b.

O Brasil da Nova Era. Rio de Janeiro: Jorge Zahar Ed., 2000.

Xamãs na cidade. REVISTA USP, São Paulo, n. 67, 2005. RUIZ, Miguel. Os Quatro compromissos. Rio de Janeiro: Best Seller, 2005.

PEREZ, Clotilde. Mascotes: Semiótica da vida Imaginária. São Paulo: Cengage Learning. 2010: 144.

PIRES, Rogério Brittes Wanderley. O Conceito Antropológico de Fetiche: Objetos Africanos, Olhares Europeus. Dissertação (mestrado) - Orientador: Márcio Goldman. Universidade Federal do Rio de Janeiro, Programa de PósGraduação em Antropologia Social Museu Nacional, 2009- Rio de Janeiro, PPGAS-MN/UFRJ, 2009.

TURNER, Terence. 2009. "The crisis of late structuralism. Perspectivism and animism: rethinking culture, nature, spirit, and bodiliness". Tipití 7(1): 1-42

SANSI, Roger. Feitiço e fetiche no Atlântico moderno. Revista de Antropologia, São Paulo, v. 51, n. 1, p. 123-153, jan. 2008. ISSN 1678-9857. Disponível em: $<$ http://www.revistas.usp.br/ra/article/vie w/27303 >. Acesso em: 15 dec. 2017. DOI: http://dx.doi.org/10.1590/S0034$\underline{77012008000100005}$

TAUSSIG, Michael - Xamanismo, colonialismo e o homem selvagem - Um Estudo Sobre o Terror e a Cera. Paz e Terra, 1993.

UNGER, Peter. Living High and Letting Die. Oxford: Oxford University Press, 1996.

VARELA, Drauzio. Macacos. São Paulo: Editora Publifolha, 2000.

VIVEIROS DE CASTRO, Eduardo. 1996. "Os pronomes cosmológicos e o 


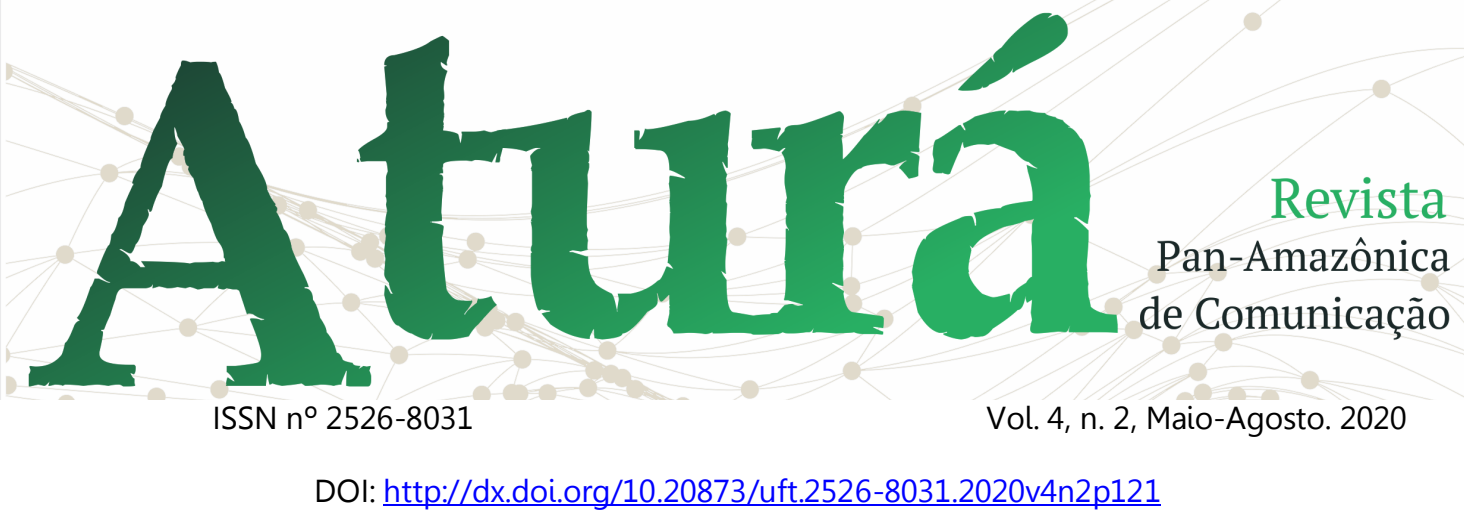

perspectivismo ameríndio". Mana 2(2):

115-144.

2002. "O nativo relativo". Mana

8(1): 113-48 